\title{
REGIONAL IMPLICATIONS OF NATIONAL CARBON TAXES
}

\author{
MARTIN T. ROSS \\ Nicholas Institute for Environmental Policy Solutions \\ Duke University, USA \\ martin.ross@duke.edu
}

Received 4 October 2017

Revised 29 December 2017

Accepted 3 January 2018

Published 20 March 2018

\begin{abstract}
This paper examines impacts of nationally-imposed carbon taxes on different regions of the United States. The goal is to see what can be learned about the drivers of regional political support for and opposition to such measures. Whether at the state, regional or national levels, carbon taxes are one option for reducing greenhouse gas emissions; several state and regional programs are already under way and lowering emissions. This analysis uses a U.S. regional version of the DIEM computable general equilibrium model to explore relationships between carbon taxes, emissions, and economic growth. One area of emphasis is how the distribution of impacts may be affected by differences in regional household spending patterns, the types of industries and electricity generation situated in those regions, and the locations of energy production and energy-intensive manufacturing. The modeling also explores how carbon tax revenues can be used to offset impacts on regional factor earnings.
\end{abstract}

Keywords: Climate policy; carbon taxes; CGE.

\section{Overview}

Carbon taxes are one of the options under consideration for reducing greenhouse gas emissions in the United States, whether at the state, regional or national levels, and several such programs are already under way. A number of recent modeling studies have looked at the economic implications of these proposals, which can lead to broad macroeconomic adjustments as firms and households seek to lower their emissions and adapt to higher energy prices. Concerns exist that these impacts - or the incidence of a carbon tax - may not be distributed evenly across the economy. There is the potential for the distributional impacts of carbon taxes to be regressive, i.e., they may have more adverse impacts on low-income households that spend a larger share of their income on energy than higher-income households. Firms are concerned about how

This is an Open Access article published by World Scientific Publishing Company. It is distributed under the terms of the Creative Commons Attribution 4.0 (CC-BY) License. Further distribution of this work is permitted, provided the original work is properly cited. 
their competitive positions may be negatively impacted both domestically and globally, especially among energy-intensive, trade-exposed (EITE) industries. The drivers behind regional variations in impacts will also be critical in determining the political feasibility of such policies.

Carbon taxes have the potential to raise substantial amounts of revenue. Studies have shown that how these revenues are used can have impacts that are larger than those of the carbon tax itself. Capital taxes reduce investment, personal income taxes lower the labor supply and distort consumption choices, and payroll taxes also reduce returns to working and thus lower economic activity. Using carbon tax revenues to lower distortions from these existing taxes (known as revenue recycling or tax swaps) can reduce overall inefficiencies caused by the tax system. This benefit, or double dividend - which occurs in addition to any benefits associated with lowering emissions - can be significant. However, most modeling work indicates that there is a policy trade-off between household distributional or equity concerns and any economic efficiencies gained by lowering existing taxes.

This paper focuses on the potential regional differences in the impacts of carbon taxes. Such differences have the potential to drive support for and opposition to instituting the policy. The paper uses a U.S. regional version of the DIEM computable general equilibrium model to explore the relationships among carbon taxes, emissions, and economic growth. Among the factors considered in the modeling are regional differences in industrial production and electricity generation, household spending patterns, and the locations of energy production. The modeling also explores how various ways of using carbon tax revenues could be used to offset policy impacts and how these options affect any region-specific impacts.

\subsection{Findings on emissions reductions under a national carbon tax policy}

In the absence of new policies, or very low gas prices, $\mathrm{CO}_{2}$ emissions are likely to increase - or at least not decrease. Carbon taxes are one way to change this outcome. Taxes lower emissions through adjusting the economics of different production technologies, household consumption and vehicle choices, and the viability of options for electricity generation. The size and speed of these adjustments will depend on the initial carbon tax level and its growth rate over time:

\section{- A $\$ 25 /$ ton carbon tax results in significant emissions reductions in the near} term: Whether the carbon tax remains relatively constant after 2020 or continues to increase, emissions from electricity generation are reduced by one-third from baseline levels by 2025 and by $15 \%$ for the economy as a whole. If the tax rate only rises by $1 \%$ per year going forward, the pace of additional reductions slows in the future years. If the rate were to increase by $5 \%$ per year, emissions would continue to decline through 2050 .

- A \$50/ton carbon tax provides even larger emissions reductions in the near term: While the $\$ 50 /$ ton tax continues to provide more reductions in the future than a lower tax rate, overtime these reductions become more difficult as few emissions 
remain and the gap between it and the $\$ 25 /$ ton tax narrows. Decarbonization of the economy is not achieved by 2050 under the higher tax rate, however, caution should be used when interpreting the long-term model findings as it is easy to underestimate structural shifts in technology as taxes encourage new methods of production and consumption of goods.

- Revenues from carbon taxes can be substantial: A $\$ 25 /$ ton tax generates around $\$ 120$ billion annually when the tax is imposed, while a $\$ 50 /$ ton tax provides slightly less than twice that amount of revenue. If tax rates are relatively steady, returns stay fairly constant, but if tax rates increase at 5\% per year, these receipts continue to increase.

\subsection{Findings on macroeconomic impacts of a national carbon tax}

The analysis estimates policy costs as changes in GDP, factor prices, and the welfare of households. Across a range of possible carbon tax rates, the modeling broadly finds the following:

- Costs of a carbon tax policy are quite low for the United States: GDP growth rates are barely affected by the carbon taxes and may actually increase, depending on how the revenues are used. After 10 years of a $\$ 25 /$ ton carbon tax growing at $5 \%$ per year, annual GDP adjustments range from an increase of $0.05 \%$ to a decrease of $0.35 \%$. Cumulative welfare costs to households, measured by changes in consumption, are of the same magnitude as these GDP impacts.

- Factor prices can be affected by the policies: Existing capital investments are likely to experience the most significant decreases in returns due to their limited ability to adjust to a lower-carbon economy. Implications of carbon taxes for new investments and labor income are less clear cut and depend on how carbon revenues are used.

- Methods of using (recycling) carbon tax revenues can have larger impacts on the economy than the carbon taxes themselves: Lump-sum recycling through direct payments to households has the fewest benefits for the economy (it may provide the most benefits to low-income households however). Using revenues to lower marginal labor taxes can increase real wage rates and help offset the economic impacts associated with adjusting to a lower-carbon future. Recycling revenues through lowering capital taxes may provide the most benefits to households as a whole, but this approach is expected to be regressive and benefit high-income households that own capital more than low-income households.

\subsection{Findings on regional impacts of a national carbon tax}

National impacts tend to obscure significant differences at the regional level. The analysis looks at how nine regions of the United States may be affected by carbon taxes. Across these regions, which have very different energy consumption and production patterns, the modeling broadly finds the following:

- Regional impacts vary significantly depending on the structure of local economies: The Northeast and West Coast are less energy intensive and have lower 
dependence on fossil generation than other parts of the nation, putting them in a good position to respond to carbon taxes. Both GDP impacts and household welfare costs of carbon policies follow these trends.

- Regional factor prices tend to follow the regional economic structures: Impacts on labor productivity and returns to existing capital stocks follow the same pattern in which the Northeast and West Coast see the smallest impacts and the middle of the country has larger adjustments.

- National approaches to recycling of tax revenues does not address regional disparities: While recycling options can lower policy costs (or eliminate them in some parts of the country), they do not change any regional advantages (or disadvantages) as areas adjust to carbon taxes.

- How capital ownership is distributed around the country matters: Most analyses assume that all capital is fully pooled across the country through national capital markets, thus dispersing policy costs across regions. To the extent that capital is locally owned - perhaps because of the rise in importance of pass-through business entities - regional variations will be exaggerated.

The remainder of this paper discusses the literature on these topics, describes the DIEM model structure and assumptions that have the largest influences on results, defines the policy scenarios investigated, and examines the model findings for a range of possible starting carbon taxes and growth rates.

\section{Background}

A number of recent studies have looked at the economic implications of carbon tax proposals. Several modeling approaches have been used to investigate implications for specific industries, the economy as a whole, and households in particular. Partial equilibrium (PE) analyses tend to focus on particular industries such as electricity (e.g., Burtraw et al., 2009) or particular areas of interest such as household distributional impacts (e.g., Dinan, 2012) or EITE industrial competitiveness (e.g., Aldy and Pizer, 2011). Household-level models in the PE framework look at distributional issues related to the "use-side" of income impacts related to carbon taxes with a fair amount of detail. These models examine how final users of goods (households) are affected by price increases associated with carbon taxes. Impacts of prices are traced through input-output data reflecting industrial production techniques, assuming that there is full pass-through of the carbon tax burden to households. The price increases of goods and services are combined with BLS Consumer Expenditure Survey (CEX) data on annual consumption patterns for different income groups to get distributional impacts of the carbon tax (e.g., Mathur and Morris, 2012). Household PE model results are a static representation of short-term distributional impacts of carbon taxes and provide revenue estimates, but do not usually estimate reductions in emissions or changes in macroeconomic variables such as GDP or any benefits of revenue recycling options. 
Other models use a computable general equilibrium (CGE) approach that covers the entire economy and can simultaneously examine both the "use-side" of income spent on final consumption goods and any "source-side" effects where carbon taxes affect income sources (labor and capital earnings). This approach reflects the fact that producers cannot pass the full burden of a carbon tax through to households. The modeling indicates that "source-side" income effects can have as significant implications for distributional equity as the "use-side" of changes in household purchase prices. Because of their broad structure, CGE models typically have less detail on different classes of households than PE models, although some studies have combined CGE models with more detailed CEX data on household purchases. Compared with static PE household analyses, CGE models have many more structural assumptions affecting estimated results including: how adjustment dynamics and household generations over time are modeled, the mobility of capital across industries (and, in some cases, regions), labor supply elasticities that control how easily workers enter and leave the work force, energy substitution elasticities that control energy efficiency improvements, and how international trade is represented. CGE models can provide estimates of changes in emissions, tax revenues, macroeconomic impacts and benefits of revenue recycling through other taxes, and household distributional issues.

Several previous organized modeling studies have looked at carbon tax issues. The Stanford Energy Modeling Forum (EMF) coordinated eight models in the EMF24 study (US Technology and Climate Policy Strategies) ${ }^{1}$ to look at GHG emissions caps, which are functionally similar in CGE models to carbon taxes. Fawcett et al. (2015) reported that, on average across the different models and assumptions, a tax rate of $\$ 41 /$ ton in 2020 would reduce emissions to $83 \%$ of 2005 levels in 2020 and a tax of $\$ 192 /$ ton in 2050 would reduce emissions to $50 \%$ of 2005 levels. There was, however, substantial variation across models on the tax rate needed to achieve these levels of reductions.

In 2015, a special issue of the National Tax Journal published five studies that use a carbon tax to raise revenue which can be used to reduce personal or corporate tax rates, or the federal debt. All the papers show that the economic impacts of a carbon tax would depend on how the revenues are used. McKibbin et al. (2015) find that in most cases a carbon tax reduces GDP, however, if revenues are used to lower capital taxes, emissions decline while GDP actually increases. Jorgenson $e t$ al. also finds that capital tax recycling can increase GDP and is also welfare improving (i.e., a "strong" double dividend). Rausch and Reilly (2015) do not find a "strong" double dividend, consistent with previous modeling efforts in the literature. Other recycling options have more mixed results, although lump-sum rebates to households are usually the least efficient as they forgo the opportunity to reduce other tax distortions. Williams et al. (2015) use a dynamic, overlapping generation (OLG) model combined with a more detailed household model and find that, while carbon taxes are regressive, accounting for the

${ }^{1}$ https://emf.stanford.edu/projects/emf-24-us-technology-and-climate-policy-strategies. 
taxes' effects on income ("source-side") can substantially reduce the estimated regressivity. In general, cutting capital taxes tends to benefit high-income households, lump-sum recycling benefits low-income households, and labor or personal income tax recycling falls in-between those two options.

Other organizations such as Brookings, the Congressional Budget Office (CBO), Massachusetts Institute of Technology (MIT), and Resources for the Future (RFF) have also been extensively involved in modeling carbon taxes over the years. Across all the studies, a number of important — and at least somewhat consistent (though with outliers) — findings have emerged:

- Emissions reductions can be significant - Carbon taxes in the $\$ 10-\$ 40 /$ ton range can lower emissions by $15 \%-30 \%$ over the next 5-10 years. Hafstead and Kopp (2016) estimate that a carbon tax priced at the estimated social cost of carbon of \$45/ton and growing at 2\%/year can reduce emissions in 2030 to $43 \%$ below 2005 levels.

- Carbon tax revenues can be substantial - in spite of the emissions reductions, the tax base of remaining emissions remains large enough to generate $\$ 1-\$ 2$ trillion over a decade. These new revenues can represent a significant fraction of CBO's estimates of government revenue streams or deficits (CBO, 2016). However, note that the Joint Committee on Taxation and the CBO, based on modeling in this area, are inclined to assume that net revenues are lower than gross revenues by $25 \%$ (the "haircut" needed to account for reductions in other tax revenue sources and increases in purchase prices for government goods caused by a carbon tax). ${ }^{2}$

- Macroeconomic impacts from a carbon tax are generally modest - Williams and Wichman (2015) review estimates of GDP impacts and find that most cluster between $0.5 \%$ and $0.7 \%$ declines by 2040 (with outliers).

- Revenue recycling through other taxes can lower policy costs - impacts on GDP and overall household consumption can be significantly reduced through lowering existing taxes.

- Generally, the most economically efficient recycling option is to lower corporate/ capital taxes, followed by personal income taxes and payroll taxes. Some studies reorder some of these tax types, depending on model structures and assumptions.

- Lump-sum recycling through direct payments to households can be significantly less efficient since it gives up the opportunity to lower existing distortions.

- Lowering the deficit/debt can also be effective, assuming that capital/labor taxes would have been raised in the future to meet debt payments. Some studies also explore the possibility for reducing interest rates by lowering government borrowing.

- Carbon taxes by themselves can be regressive - they can impose disproportionate burdens on low-income households because they spend a higher share of their income on energy.

\footnotetext{
${ }^{2}$ Rausch and Reilly (2012) estimate a haircut closer to 30\%, although it varies.
} 
- PE studies that focus on the "use-side" of income (i.e., spending on household goods that have risen in price) tend to see this effect.

- CGE models also see this, however, some studies indicate that effects on "sourceside" of income (changes in capital and labor earnings) can be progressive.

- How policy costs are measured can influence these results - annual income versus some proxy for lifetime income such as annual consumption.

\section{- Uses of carbon tax revenue have more important distributional effects than the tax itself}

- Distributional impacts tend to run counter to economically efficient recycling options.

- Lump-sum rebates to households are progressive (but economically inefficient).

- Lowering income taxes does not benefit the lowest-income groups that pay few taxes - other options such as the Earned Income Tax Credit (EITC), Supplemental Nutrition Assistance Program (SNAP), or Low Income Home Energy Assistance Program (LIHEAP) can help low-income households. Mathur and Morris (2012) suggest that using $11 \%$ of the revenues from a $\$ 15 /$ ton carbon tax can keep the poorest two deciles whole.

- Payroll tax or personal income tax reductions are more regressive than lump-sum recycling (the degree of regressivity varies across studies).

- Capital or corporate tax recycling is likely to provide the most benefits to upperincome households, making it the most regressive but most economically efficient option.

- OLG modeling indicates that generational equity issues can also be important (Williams et al., 2015).

In spite of this recent literature, there remain a number of open questions regarding the modeling of carbon tax impacts, whether it is where model results disagree on important issues such as the details of distributional impacts or where topics are relatively unexplored. Among these questions are: how will estimated impacts change when model forecasts are updated to current economic and energy-market conditions, how sensitive are results to model structure and assumptions, and how will carbon tax impacts and distributional outcomes vary across regions of the country.

Economic conditions have changed dramatically in recent years. Even though GDP growth and tax receipts have been relatively robust, $\mathrm{CBO}$ (2016) projections indicate that the federal budget deficit is likely to continue increasing over the next decade. This may motivate carbon taxes as a new source of government revenues as a way to reduce deficits or offset increases in other types of taxes since, depending on the carbon tax chosen, they could raise $\$ 100-\$ 200$ billion dollars annually.

The amount of revenue raised by a carbon tax will depend on emissions in the economy, as they form the tax base for the policy. Low baseline emissions (in the absence of a carbon tax) will lower the prospective tax base for a policy regime. 
Conversely, low natural gas prices, which have already reduced economy's reliance on coal, may leave only higher-cost abatement activities available to reduce emissions, thus making a carbon-tax policy more costly by lowering economic activity. The level of emissions and the costliness of remaining reduction opportunities will affect both the revenues raised by carbon taxes and the impacts of reductions on the economy.

The choices made by modelers regarding model structure will also affect the types of insights gleaned from policy investigations. Processes such as the Stanford EMF32 study that compare policy results across a range of models are helpful in illuminating how different model assumptions may affect findings. While there is some literature on the distributional impacts of carbon taxes as discussed above, more work is needed to sort out varying findings across studies.

Along with unanswered questions about how recent changes in the economy and emissions will affect carbon taxes, another area of interest is how impacts of the taxes will be distributed around the country. Some recent literature has indicated that regional variation is not a significant factor (e.g., Mathur and Morris, 2012; Carbone et al., 2013; Williams et al., 2015). However, most PE or CGE models used to look at regional variation start with a national structure that estimates a single change in factor market earnings (national-level wage rates and capital returns) and then use CEX data to share impacts out to more disaggregated households at the state or regional level. Thus, they cannot account for potential differences in carbon tax impacts across regional income sources. Other model results such as Rausch et al. (2011) that account for differences in regional income suggest that regional distributional issues may be more important than expected.

This analysis will seek to provide new information on potential carbon-tax policy impacts by exploring the issues using a CGE model with a structure that is different from others, as is described in more detail in the next section. Features of the model's capital structure can influence how carbon taxes affect both capital and labor earnings. The model also has the ability to look at changes in regional income and model assumptions driving these results. The distribution of policy impacts across income sources and regions may play an important role in the political feasibility of such environmental policies.

\section{Model and Assumptions}

To evaluate the results of a carbon-tax policy analysis, it is first necessary to understand the type of model being used in the analysis, its main assumptions, and the model structure that drives the results. This section highlights these features of an updated version of the Dynamic Integrated Economy/Energy/Emissions Model (DIEM) used in this analysis, developed at Duke University's Nicholas Institute for Environmental Policy Solutions. ${ }^{3}$

\footnotetext{
${ }^{3}$ See Ross $(2014 a, b)$ for documentation of the previous version of DIEM, using older assumptions with a lower level of detail.
} 
DIEM includes a macroeconomic or computable general equilibrium component (DIEM-CGE) and an electricity dispatch component that provides a detailed representation of U.S. regional electricity markets (DIEM-Electricity). This analysis focuses on the macroeconomic side of DIEM, which is a dynamic multi-region, multi-sector CGE model of the global and U.S. regional economies. It is designed to look at a wide range of domestic and international policies related to the economy, energy, trade, and greenhouse gas (GHG) emissions. The CGE component combines a consistent theoretical framework with real-world data on how economies are structured, firms' production technologies, trade and investment decisions, and households' income and spending patterns in order to estimate how changes in one part of the economy will flow through to all other areas.

While DIEM's broad structure is similar to other energy-related CGE models, equations in DIEM place a special emphasis on how capital can be substituted for energy in order to achieve improvements in energy efficiency. These responses are calibrated to forecasts from the U.S. Energy Information Administration's (EIA) National Energy Modeling System (NEMS). Separately, reactions in the electricity generation sector of the CGE component are calibrated to the changes seen in policy simulations in the DIEM-Electricity model. Using results from the detailed electricity dispatch component of DIEM allows changes in generation across regions and types of generation to be consistent across the two models. However, avoiding a "hard linkage" between the models - which attempts to iterate to a consistent solution across the two models - eliminates concerns with the CGE model's welfare results that arise because of the very different approaches to capital earnings in CGE versus electricity dispatch models.

In the model, a classical Arrow-Debreu equilibrium (Arrow and Debreu, 1954; Arrow and Hahn, 1971) is specified where rational economic agents respond through price-dependent market interactions to reach an equilibrium in which supplies equal demands (for all goods with a positive price). Firms' maximize profits subject to their technology constraints, and households with perfect foresight maximize utility subject to incomes from sales of factors of production equaling their expenditures. Governments collect tax revenue, purchase goods, and transfer money among households. DIEM-CGE is formulated and solved as a mixed complementarity problem (MCP) using the GAMS mathematical programming and optimization software (GAMS, 2012). It is made possible by the use of the MPSGE language (Rutherford, 1999, 2004) that allows the model to be formulated through nested constant-elasticity-of-substitution (CES) equations used to describe firm and household behaviors.

The DIEM-CGE model has two distinct macroeconomic components, Global and U.S. Regional, both of which rely on the same model structure. The two regional models are linked through trade impacts determined by the Global component of the model so that, when examining policy impacts on U.S. regions, it is possible to account for any changes at a global level that affect subnational areas of the United States. Of particular interest in DIEM-CGE are the impacts of energy and GHG 
policies. Accordingly, the model considers implications of policies for energy consumption and hence carbon dioxide $\left(\mathrm{CO}_{2}\right)$ emissions. It also includes five non- $\mathrm{CO}_{2}$ gases in an endogenous fashion. Economies grow over time as a function of several factors (labor force and labor productivity growth, capital accumulation through investment, changes in supplies of natural resources, and improvements in technology) when establishing a baseline forecast from which predictions of policy impacts can be made.

For this analysis, several DIEM model features will be critical in determining impacts of carbon tax and revenue-recycling policies. Findings will be controlled by the following model data and assumptions:

(1) Energy data and baseline forecasts of economic growth, energy supply and demand.

(2) Capital and labor tax rates.

(3) Capital structure in the model and representation of energy-efficiency improvements.

(4) Labor supply elasticities.

(5) Household consumption patterns and regional ownership of labor and capital.

The starting point for evaluating model results is understanding the energy data and forecasts used in the model. A large portion of the data used in DIEM focus on describing energy production and consumption decisions, especially those related to electricity, and associated GHG emissions levels. This emphasis allows the macroeconomic side of the model, using its internal equations specifying energy- and emissions-reductions options, to evaluate how policies related to energy may affect the broader domestic and global economies. These model inputs combine global economic data from GTAP (Narayanan et al., 2008) and U.S. state-level economic data (IMPLAN, 2012) with energy data and forecast from the World Energy Outlook, WEO (IEA, 2016) and the Annual Energy Outlook, or AEO, for the U.S. (EIA, 2017a). Historical energy data from the State Energy Data System (EIA, 2017c) and the Electric Power Annual (EIA, 2017d) are merged with the historical IMPLAN statelevel economic data, which has been updated using current state GDP data from the Bureau of Economic Analysis (BEA, 2017) and population projections from the Census Bureau (Census, 2017). GHG emissions data and forecasts are also included in the model (EPA, 2012, 2017). The historical data, represented as social accounting matrices (SAM), describe a snapshot of industrial output, current production technologies, household income sources and purchase patterns, investment and government decisions, and trade flows around the world. The economic and energy forecasts from the WEO and AEO that provide a baseline or "business-as-usual" (BaU) forecast that is the starting point for policy analyses in the model.

Next, labor and capital tax rates (among others) must be established for the model. Existing taxes and their associated distortions in the economy will affect how carbon 
taxes interact with the economy and household income and spending. Taxes in the model are collected by government agents in both the global and U.S. regional components of DIEM, who then purchase goods and services, factors of production, and also transfer revenues among households. The types of taxes collected are based on several sources. Both the GTAP global database and the IMPLAN state-level information include some tax rates. GTAP has factor and output taxes, as well as placing a special emphasis on trade tariffs. The IMPLAN data cover FICA taxes on labor earnings, property taxes, and some output taxes. These U.S. data are supplemented with information from the National Bureau of Economic Research's (NBER) TAXSIM model (Feenberg and Coutts, 1993), which provides combined federal and state marginal personal income tax rates by income source and state. These data cover taxes on the different sources of household income; including wages, dividends, interest payments, and long-term capital gains.

Capital income represents a special case, in that it can be subject to double taxation that must be taken into account when estimating capital tax rates for the model. Effective marginal capital tax rates, which affect investment incentives and help determine economic impacts of carbon taxes, are a combination of personal income taxes on capital earnings (from NBER) and corporate income taxes. Over the last couple of decades, the amount of business earnings subject to corporate income taxes has declined as businesses have altered their structures to avoid these taxes. According to the Internal Revenue Service (IRS, 2017), in 2012 63\% of business income was taxed as personal income using pass-through forms of organization. This leaves $37 \%$ of business earnings subject to the double taxation of corporate taxes and personal income taxes. Calculating an effective capital tax needs to account for this shift in shares.

For capital taxes at the federal level, the Congressional Budget Office (CBO, 2014) has estimated effective marginal capital tax rates (METR), based on business structures, types of assets, and industry-specific rules for depreciation (see Table 1). Such marginal rates represent the highest tax rate paid on the last dollar of capital earnings, and are the rates used to establish the tax distortions in models such as DIEM-CGE. On average, they estimate that $\mathrm{C}$ corporations on average face a $31 \%$ METR and passthrough entities face a $27 \%$ METR. For the DIEM model, these data have been combined with regional data on industry earnings from IMPLAN, and state corporate tax rates (Tax Foundation, 2017a), to estimate regional METR for capital earnings by industry and broad regional groups. A point of comparison for these marginal capital tax rates is the statutory corporate tax rate of around 39\% (e.g., Tax Foundation, 2017b). In practice, the Government Accountability Office (GAO, 2013) has estimated that the average corporate income tax rate on profitable businesses is $13 \%$ (federal taxes) to $17 \%$ (including state, local, and foreign taxes).

The next critical components in determining how carbon taxes will affect the economy and existing taxes are the equations that control energy-efficiency improvements. In DIEM-CGE, there are several factors to consider; first, the representation of capital stock dynamics; second, how production technologies are 
Table 1 . Estimated capital tax rates by industry and region of the country.

\begin{tabular}{lccccccc}
\hline & $\begin{array}{c}\text { Electricity } \\
(\%)\end{array}$ & $\begin{array}{c}\text { Natural } \\
\text { Resources (\%) }\end{array}$ & $\begin{array}{c}\text { Petroleum } \\
\text { Refining }(\%)\end{array}$ & $\begin{array}{c}\text { Agriculture } \\
(\%)\end{array}$ & $\begin{array}{c}\text { Manu- } \\
\text { facturing }(\%)\end{array}$ & $\begin{array}{c}\text { Services } \\
(\%)\end{array}$ & $\begin{array}{c}\text { Transport } \\
(\%)\end{array}$ \\
\hline Northeast & 34 & 30 & 36 & 34 & 38 & 37 & 32 \\
Southeast & 32 & 33 & 40 & 32 & 36 & 35 & 30 \\
East Central & 36 & 25 & 32 & 36 & 40 & 39 & 34 \\
South Central & 28 & 29 & 37 & 30 & 32 & 30 & 26 \\
North Central & 32 & 28 & 37 & 34 & 37 & 36 & 30 \\
West & 32 & 0 & 0 & 33 & 37 & 36 & 31 \\
\hline
\end{tabular}

Source: Author's calculations based on CBO (2014).

represented; and, finally, the calibration of energy-demand elasticities to the capitaldynamics and production-technology equations.

How the evolution of capital stocks over time is represented will determine how quickly the economy can respond to a carbon-tax policy. DIEM-CGE is a forwardlooking, fully intertemporal optimization model in which households have perfect foresight and plan ahead to minimize any costs of future policies announced today. However, these dynamics have both short- and long-run components, which accomplished by distinguishing between malleable and nonmalleable capital stocks in the model.

This partial "putty-clay" approach (see Phelps, 1963; Lau et al., 2002) is adopted to separate the two types of capital. Initially, there is an existing "clay" capital stock that depreciates away over time and produces with a Leontief technology based on input shares shown in the historical economic data (i.e., this capital continues to produce with today's technology as shown in the historical GTAP/IMPLAN data in the model without efficiency improvements). Both initially and over time, investments can be made in several types of new malleable, or "putty," capital stocks (i.e., manufacturing, housing, and personal vehicles) that do have options for energy efficiency improvements. The relative shares of "putty" versus "clay" capital in each sector of the economy play a role in determining the ease of energy-efficiency improvements in the short- and long-run.

In the manufacturing sector (and other sectors), the "putty" equations are represented using nested CES equations. Production technologies of firms in the model involve trade-offs among inputs of capital (K), labor (L), energy (E), and material (M) inputs. These CES equations describe how technologies can change in response to increases in energy prices. The DIEM model broadly follows some elements of the approach used in other CGE models focused on energy and environmental policies (e.g., Paltsev et al., 2005), and assumes that a composite KLE good is combined with materials inputs in fixed proportions in the first level of a nested CES function. Elasticities of substitution lower down in the CES structure then control, for example, how easy it is to substitute into capital or labor and out of electricity if the price of 
electricity rises. If firms are very willing and able to substitute capital or labor for electricity, the price of a firm's output will not change much when electricity prices rise and vice versa. Thus, choice of these elasticities related to energy efficiency is a critical feature determining the model's policy-cost estimates.

Where the DIEM-CGE model structure differs from many other models is in its adoption of an explicit link between capital and energy (the US-REGEN model has a similar structure in the housing sector - EPRI 2017). This link, shown for manufacturing in Fig. 1, separates capital into a value-added component and an energy-services component. Thus, the elasticity between capital and an energy composite in the energy-services nest controls the ease of energy-efficiency improvements in the "putty capital" production technology (value-added elasticities are Cobb-Douglas, following other CGE models). Other sectors in the model adopt a similar capitalenergy structure - whether for transportation, household services, or electricity generation (see the appendix for details).

Calibration of DIEM-CGE to desired energy-demand elasticities over the model's forecast horizon has to account for: The presence of malleable and nonmalleable capital, the rate at which the nonmalleable stock depreciates away over time, and the capital-energy substitution options in the production equations illustrated above. This calibration is done for four different sectors of the economy - residential, commercial, industrial, and transportation - based on a combination of energy demand responses in the Annual Energy Outlook and the literature more broadly. ${ }^{4}$ Similar to

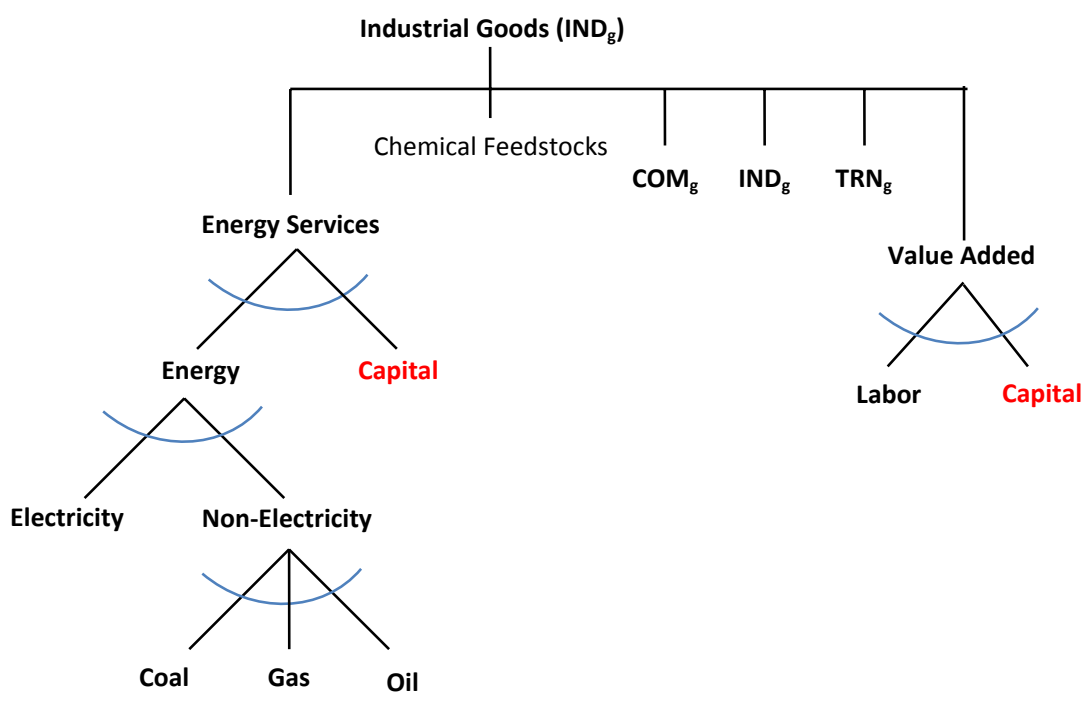

Figure 1. Manufacturing

\footnotetext{
${ }^{4}$ Energy-substitution options (based on specific technology choices) in electricity generation are calibrated to results from the detailed electricity dispatch component of the model, DIEM-Electricity, as discussed in the appendix.
} 
the approach mentioned in Lanz and Rausch (2011), simulating demand elasticities in DIEM-CGE involves exogenously increasing the price of a single energy type in one of the four broad sectors of the economy and evaluating the change in energy demand. This is accomplished through a tax on the type of energy in each sector, where any tax revenues are returned to households in a lump-sum, nondistortionary fashion to avoid income effects.

Once the historical data on the economy, production technologies, and tax rates are combined with the calibrated CES equations that control policy responses, it is then necessary to choose labor-supply elasticities for the model. The distortions in the economy caused by pre-existing marginal capital and labor taxes are a function of how the labor-supply responds to changes in wage rates in the model. In formulating the DIEM-CGE model, households choose between consumption of good and leisure time when determining intratemporal (within time period) utility. The elasticity of substitution between these two commodities can be calibrated to give a desired labor supply elasticity (Ballard, 2000). Based on the literature, DIEM-CGE is calibrated to have 0.3 (0.05) for the compensated (uncompensated) labor supply elasticities (see Rausch and Mowers, 2012). ${ }^{5}$ In choosing these values, measures of the tax distortions (marginal excess burden and marginal cost of public funds) were also assessed.

Finally, the model must include data on regional household consumption patterns and income sources. The IMPLAN state-level data has information on consumption, which have been updated with recent information from the Bureau of Labor Statistic's (BLS, 2016) Consumer Expenditure Survey (CEX). Household income is derived through the sale of factors of production (labor, capital, and natural resources). With the exception of extant (existing) capital that is fixed within a particular sector, labor and capital are assumed to be fully mobile intersectorally. Labor is immobile across regions so that changes in utility for the representative households can be calculated in the model. New capital investments typically earn an expected rate of based on U.S. capital markets (international borrowing and lending over time is also allowed). Across regions of the U.S., households own the labor located within a region and also shares of a pooled account of capital and natural resources where ownership is distributed through national capital markets.

This assumption of pooled national ownership of capital and resources is relaxed in some policy scenarios to investigate regional implications of localized capital ownership. Given that $63 \%$ of business income is earned by pass-through entities, there may be difficulties with the standard modeling assumption that national ownership of capital will smooth earnings across regions, and it may be more likely that regional differences in carbon-tax impacts will play an important role in how households

\footnotetext{
${ }^{5}$ Russek (1996) and Fuchs et al. (1998) provide a survey of labor supply elasticities. The elasticities from Rausch and Mowers are similar to those in Bovenberg and Goulder (1996), Goulder et al. (1997), Williams (1999), and Parry et al. (2000).
} 


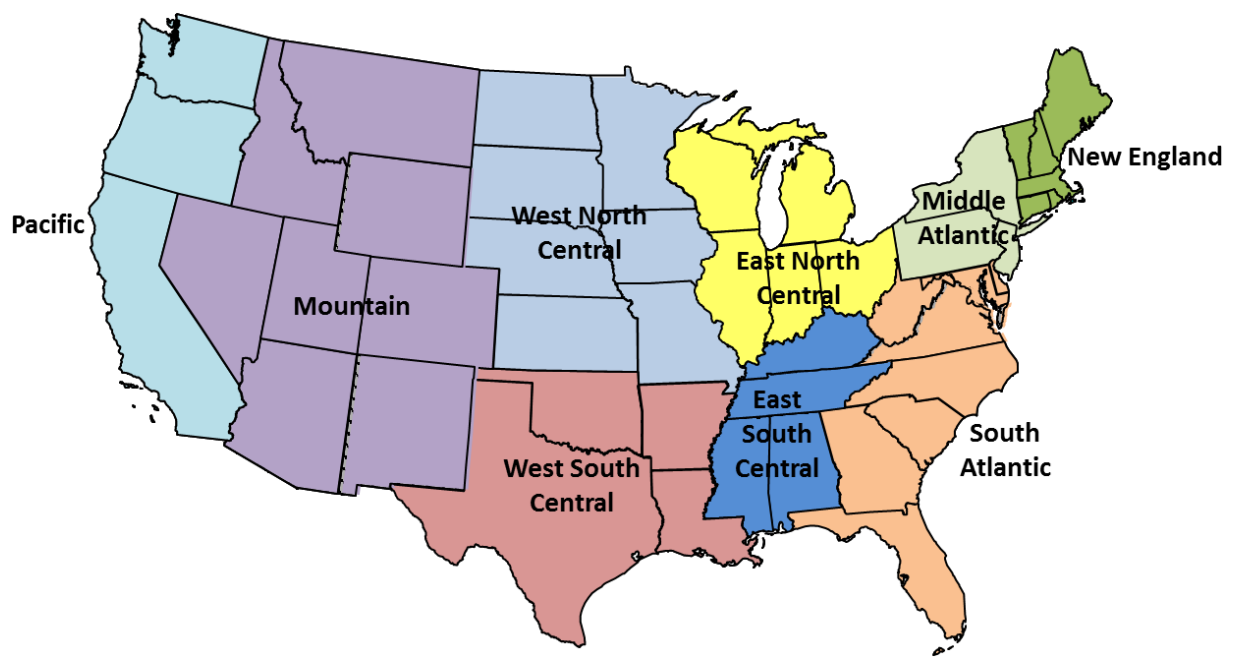

Figure 2. EIA Census regions

respond to such policies. To investigate these possibilities, modeling results are presented for the nine Census regions (Fig. 2).

Variations in regional impacts of carbon taxes will depend in large part on differences in the structure of the economies. Figure 3 shows fossil-fuel energy intensities of the United States and the nine regional economies, measured in Btus of energy per dollar of GDP in 2020. Some regions, largely the East and West Coasts, are

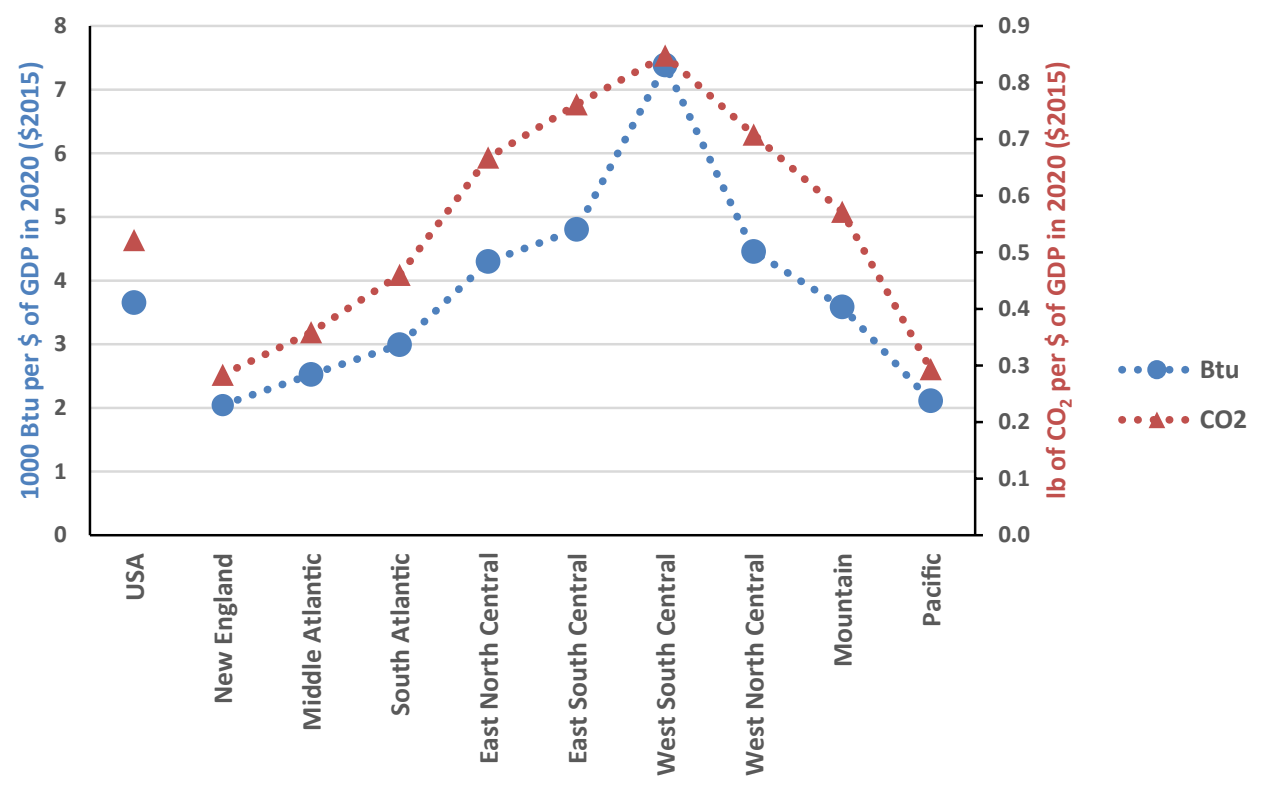

Figure 3. Regional energy and $\mathrm{CO}_{2}$ intensities in 2020 


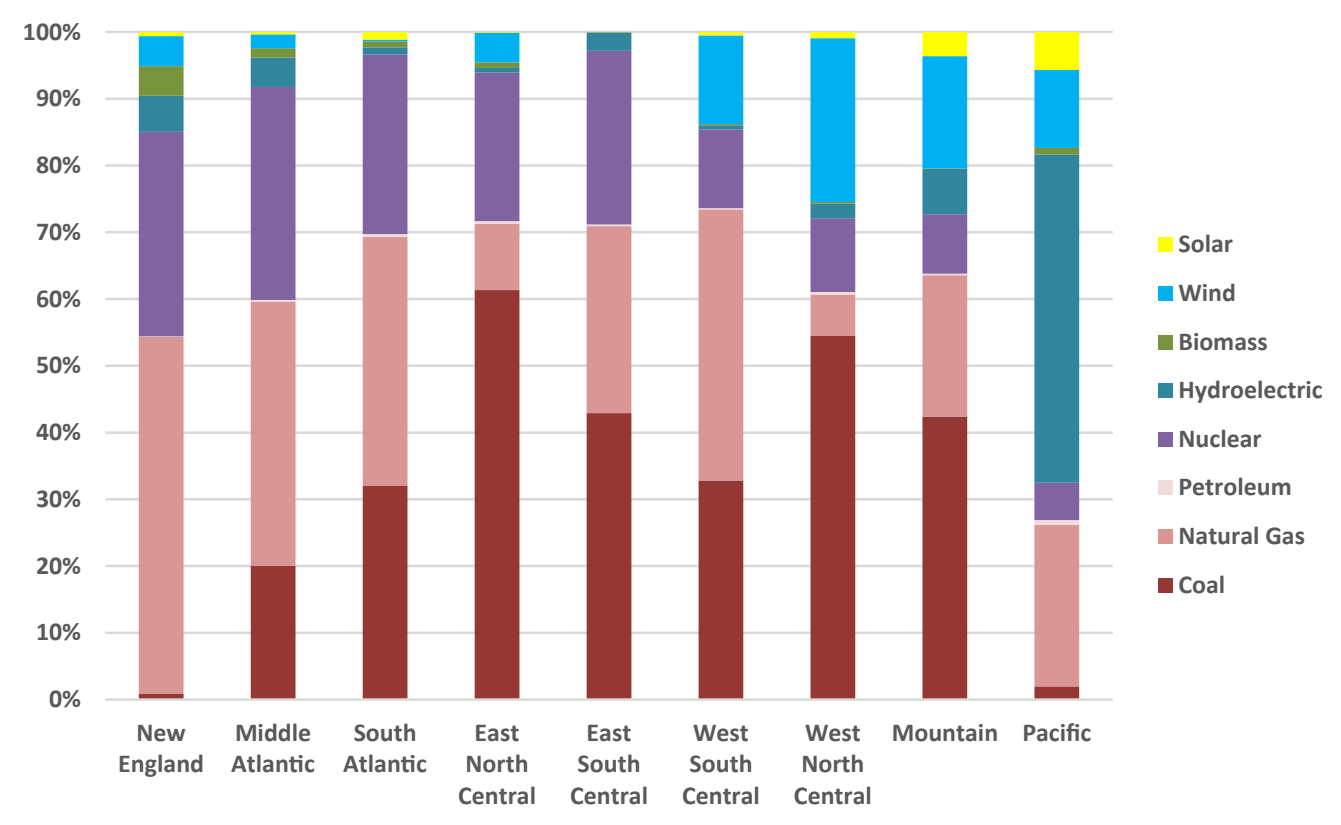

Figure 4. Baseline regional generation shares by type (2020)

significantly less energy intensive than the center of the country. Emissions of $\mathrm{CO}_{2}$ largely follow the same regional pattern.

A major driver of regional differences in fossil-fuel consumption and $\mathrm{CO}_{2}$ emissions is the types of electricity generation across the nation. Figure 4 illustrates baseline shares of the different types of generation in 2020. Over the last decade, the generation mix of the country has shifted away from coal and into natural gas. Some regions, however, remain dependent on coal as a major fuel source for generation. This leads to higher emissions, but also potentially cheaper options for reducing emissions.

As with overall energy intensities, coal-fired plants are more predominant in the middle of the country and so less on the coasts. New England has capped $\mathrm{CO}_{2}$ emissions from electricity for a number of years through the RGGI program. In the Pacific region, California also has policies that restrict fossil generation, combined with significant hydroelectric resources in the Northwest, leading to lower emissions from this component of the regional economies.

Across the nation as a whole, electricity generation represents a large share of current and forecasted emissions (see Fig. 5). This sector is expected to respond relatively quickly to carbon taxes since they can shift the economics of coal versus gas generation, and also shift generation into renewable resources. Other sectors of the economy can have a harder time responding. The figure generally aggregates emissions sources into the categories shown in EIA's AEO 2017, however, it separates personal light-duty vehicles (LDV) from other types of transportation. LDV emissions can be reduced in the model both through efficiency improvements in conventional 


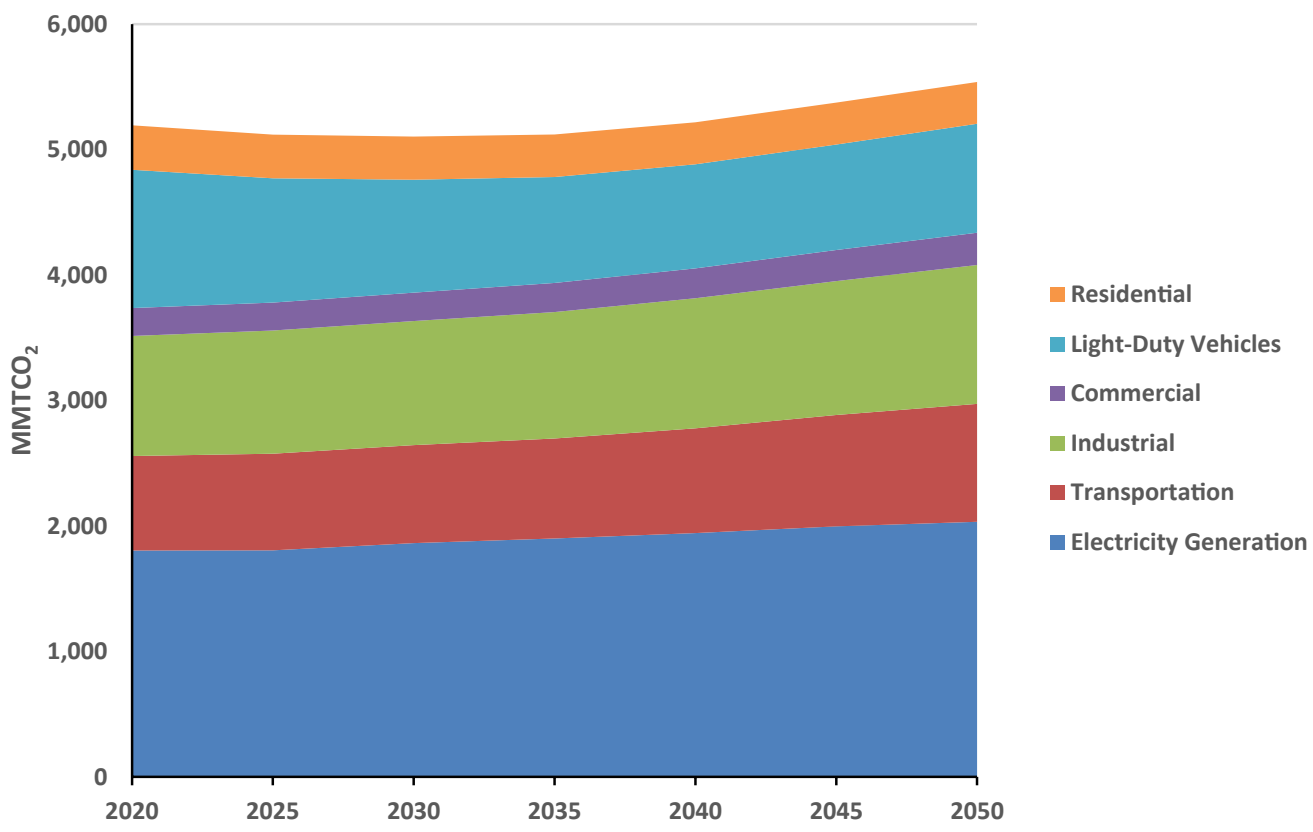

Figure 5. Baseline $\mathrm{CO}_{2}$ emissions by sector

internal-combustion vehicles and through shifting into lower/nonemitting vehicles such as electric cars. Other sectors of the economy can have a harder time reducing emissions in response to carbon taxes - at least according to the demand elasticities in the AEO forecasts that help inform calibration of policy responses in the DIEM model.

\section{Policy Scenarios}

Starting from these baseline conditions, the DIEM model is used to explore how pricing carbon emissions will lower emissions, alter macroeconomic conditions, and affect households across the country. The results focus on economy-wide impacts and the ways in which the collected revenues can be used. See Ross (2018, forthcoming) for a detailed investigation of how carbon taxes might affect electricity generation.

Several starting carbon tax levels and growth rates are defined to cover a wide range of possible policy scenarios, all of which begin in the year 2020:

- " $\$ 25 /$ ton $+1 \% "$ - A starting tax of $\$ 25$ per ton of $\mathrm{CO}_{2}$, growing at $1 \%$ per year after 2020 .

$\Rightarrow 2030$ price of $\$ 28 /$ ton, 2040 price of $\$ 31 /$ ton, 2050 price of $\$ 34 /$ ton

- “\$25/ton $+\mathbf{5 \%}$ " - A starting tax of $\$ 25$ per ton of $\mathrm{CO}_{2}$, growing at $5 \%$ per year after 2020 .

$\Rightarrow 2030$ price of $\$ 41 /$ ton, 2040 price of $\$ 66 /$ ton, 2050 price of $\$ 108 /$ ton 
- "\$50/ton $+\mathbf{1 \%} "$ - A starting tax of $\$ 50$ per ton of $\mathrm{CO}_{2}$, growing at $1 \%$ per year after 2020.

$\Rightarrow 2030$ price of $\$ 55 /$ ton, 2040 price of $\$ 61 /$ ton, 2050 price of $\$ 67 /$ ton

- "\$50/ton $+\mathbf{5 \%}$ " - A starting tax of $\$ 50$ per ton of $\mathrm{CO}_{2}$, growing at $5 \%$ per year after 2020.

$\Rightarrow 2030$ price of $\$ 81 /$ ton, 2040 price of $\$ 133 /$ ton, 2050 price of $\$ 216 /$ ton.

In addition to these core policy scenarios, several revenue recycling options are investigated: lump-sum in which carbon tax receipts are returned to households on a per capita basis, labor-tax recycling in which receipts are used to lower marginal labor tax rates, and capital-tax recycling in which receipts are used to lower marginal capital tax rates. To explore how differential ownership of labor, capital and natural resources may affect regional impacts of carbon taxes, three methods of pooling capital through national markets are considered: $100 \%$ pooled national capital, $50 \%$ pooled and $50 \%$ locally owned, and $100 \%$ locally-owned capital. Total government tax receipts are maintained through the federal (and regional) governments retaining enough carbon revenue to offset declines in other tax receipts.

\section{Policy Results}

The analysis of carbon taxes begins with an examination of emissions projections compared to baselines without the tax policy. Emissions impacts by sector under the policy scenarios are then presented. The analysis next looks at some additional details of emissions trends such as the amount of revenue that might be raised by the policies, before examining policy impacts on factor prices and GDP across the revenue recycling options. Finally, comprehensive welfare measures of the overall policy costs are examined at the regional level.

\section{1. $\mathrm{CO}_{2}$ emissions and carbon tax revenues}

The main goal of a carbon tax is to reduce emissions across the economy. Figure 6 illustrates how the various carbon tax rates would affect emissions levels, compared with the baseline trend in the absence of a carbon tax or other restrictions on emissions. Either of the starting rates, $\$ 25 /$ ton or $\$ 50 /$ ton, results in a large initial drop as the economy reduces emissions, especially from coal generation, and people anticipate the upcoming carbon taxes.

After 2020 , carbon tax rates that increase by $1 \%$ per year continue to have some impact on emissions trends, although the effects are relatively minor. Tax growth rates of 5\% per year have more substantial effects over time. In 2030, reductions from baseline range from $15 \%-25 \%$ for the $\$ 25 /$ ton taxes and 30\%-40\% for the $\$ 50 /$ ton taxes. By 2050 , emissions differences between a starting tax of $\$ 25 /$ ton and $\$ 50 /$ ton, if they grow at $5 \%$ per year, are relatively small, with reductions of $60 \%-70 \%$ from 


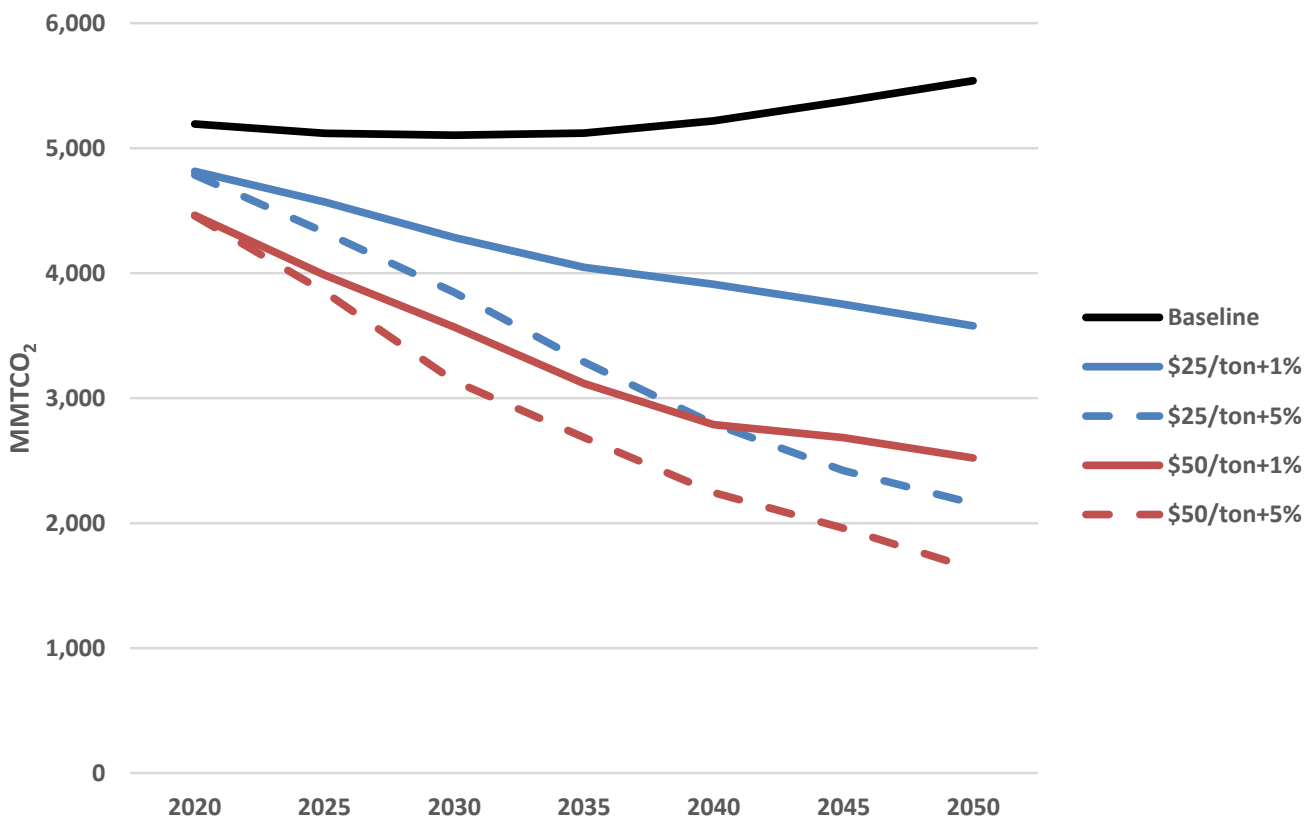

Figure 6. U.S. $\mathrm{CO}_{2}$ emissions in the baseline and alternative carbon taxes.

baseline. However, neither of the options results in full decarbonization of the economy or reach long-term goals such as an $80 \%$ reduction below 2005 levels.

Figure 7 focuses on the $\$ 25 /$ ton carbon tax, growing at $5 \%$ per year, and illustrates which sectors of the economy are providing the emissions reductions. The electricity sector provides the most reductions with other sectors contributing smaller amounts, depending on how cost effective their reduction options are. The LDV fleet experiences fairly significant adjustments as new types of vehicles replace conventional ICE vehicles, and emissions fall by $60 \%$ from baseline levels by 2050 even as vehicle miles traveled increase over time. The industrial sector reduces emissions by close to $50 \%$ by 2050, while the residential and commercial sectors have around $25 \%$ reductions and the transportation sector (aside from LDV) is less than $20 \%$.

Figure 8 for the $\$ 50 /$ ton tax, growing at $5 \%$ per year, indicates that, below 2,000 $\mathrm{MMTCO}_{2}$, it becomes increasingly difficult for the model to find cost-effective options to remove emissions from the economy. The electricity sector has been decarbonized quickly and emissions in the personal LDV category have shrunk significantly, however other emissions sources remain. While less than 25\% of baseline LDV emissions remain in 2050 , more than $50 \%$ of residential and commercial emissions are still around, along with almost $75 \%$ of baseline transportation emissions.

The most rapid adjustments, and hence reductions in emissions, occur in the electricity industry. Figure 9 illustrates generation shifts across sources in the shortand intermediate term. In the baseline without new environmental policies, coal generation is predicted to maintain a relatively constant share of total U.S. generation for 
M. T. Ross

6,000

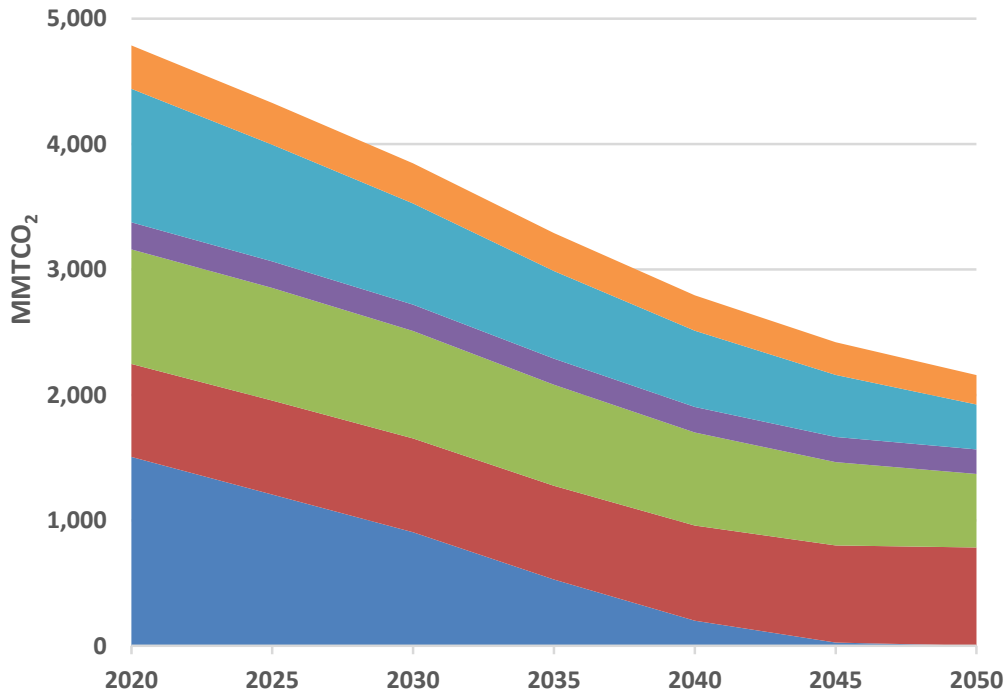

Residential

- Light-Duty Vehicles

- Commercial

- Industrial

- Transportation

n Electricity Generation

Figure 7. U.S. $\mathrm{CO}_{2}$ emissions by sector under a $\$ 25 /$ ton carbon tax growing at $5 \% /$ year

6,000

$$
5,000
$$

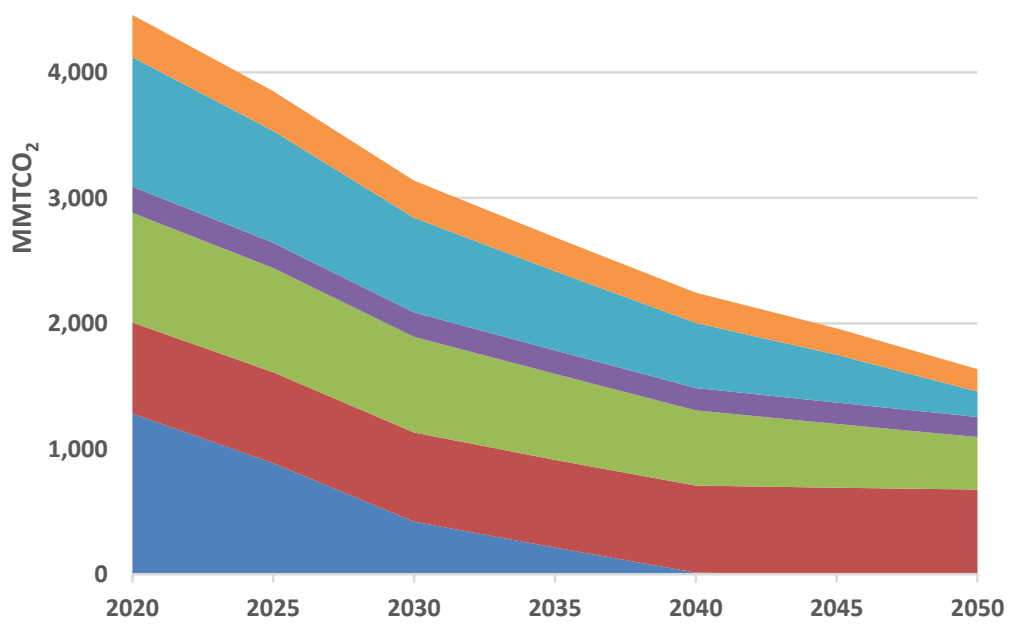

Residential

Light-Duty Vehicles

- Commercial

- Industrial

- Transportation

- Electricity Generation

Figure 8. U.S. $\mathrm{CO}_{2}$ emissions by sector under a $\$ 50 /$ ton carbon tax growing at $5 \% /$ year 


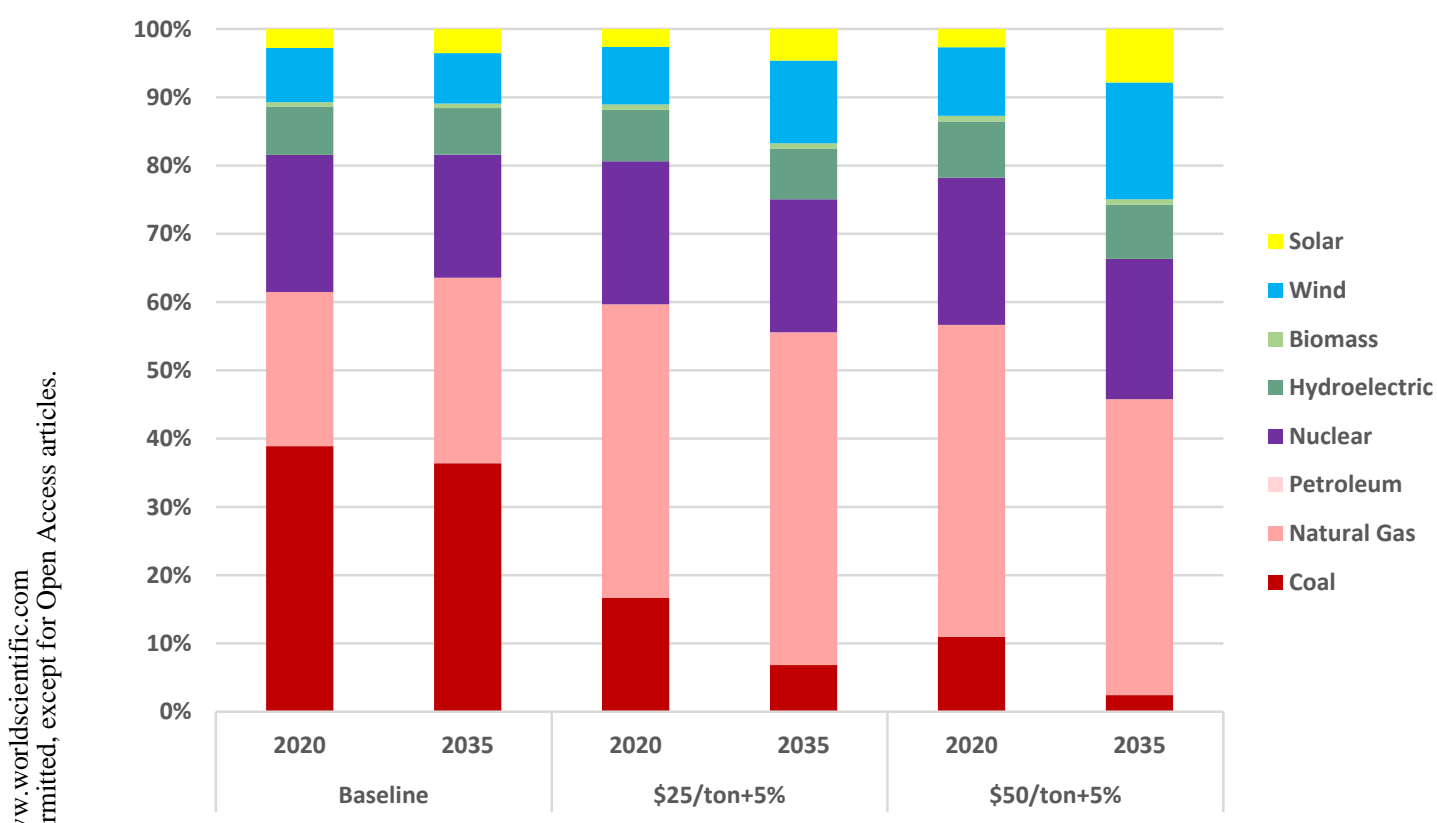

Figure 9. U.S. electricity generation shares: baseline versus alternative carbon taxes

the next couple of decades. Natural gas expands slightly in importance as the result of cheap gas supplies and a few additional coal retirements. Wind and solar grow somewhat in the baseline as construction costs decline (based on AEO 2017 and NREL forecasts). ${ }^{6}$ Through 2035, the nuclear share is roughly the same. Any nuclear retirements, assuming a 60-year lifetime, begin to occur around this time and would be replaced with mostly natural gas units, if nuclear licenses are not extended to 80 years.

In the carbon-tax scenarios, coal units retire quite rapidly. In the short term, total electricity supplied to the grid is made up by running existing natural gas units more maintaining the net load delivered to the grid and avoiding any near-term disruptions or reliability concerns. In the longer term, coal plants continue to retire and are replaced by several types of generation. In the $\$ 25 /$ ton scenario, new NGCC units offset much of the decline in coal generation by 2035. Some additional wind and solar generation also enters. In the $\$ 50 /$ ton scenario, most coal has left the system. New NGCC with CCS becomes a cost-effective response at these carbon-tax levels. Renewables also play a much bigger role in the system. As in the baseline, penetration of renewables depends on capital-cost assumptions. The standard assumptions in this analysis from AEO 2017 are relatively conservative with regards to improvements in solar photovoltaic (PV) prices. More optimistic price trends for PV and wind prices lead to much larger renewable shares in both the baseline and carbon-tax policy cases (see Ross, 2018, forthcoming).

\footnotetext{
${ }^{6}$ Renewable penetration is quite sensitive to capital costs and natural gas prices. See Ross (2018, forthcoming) for additional sensitivity analyses of generation choices in the baseline and carbon-tax policy scenarios.
} 


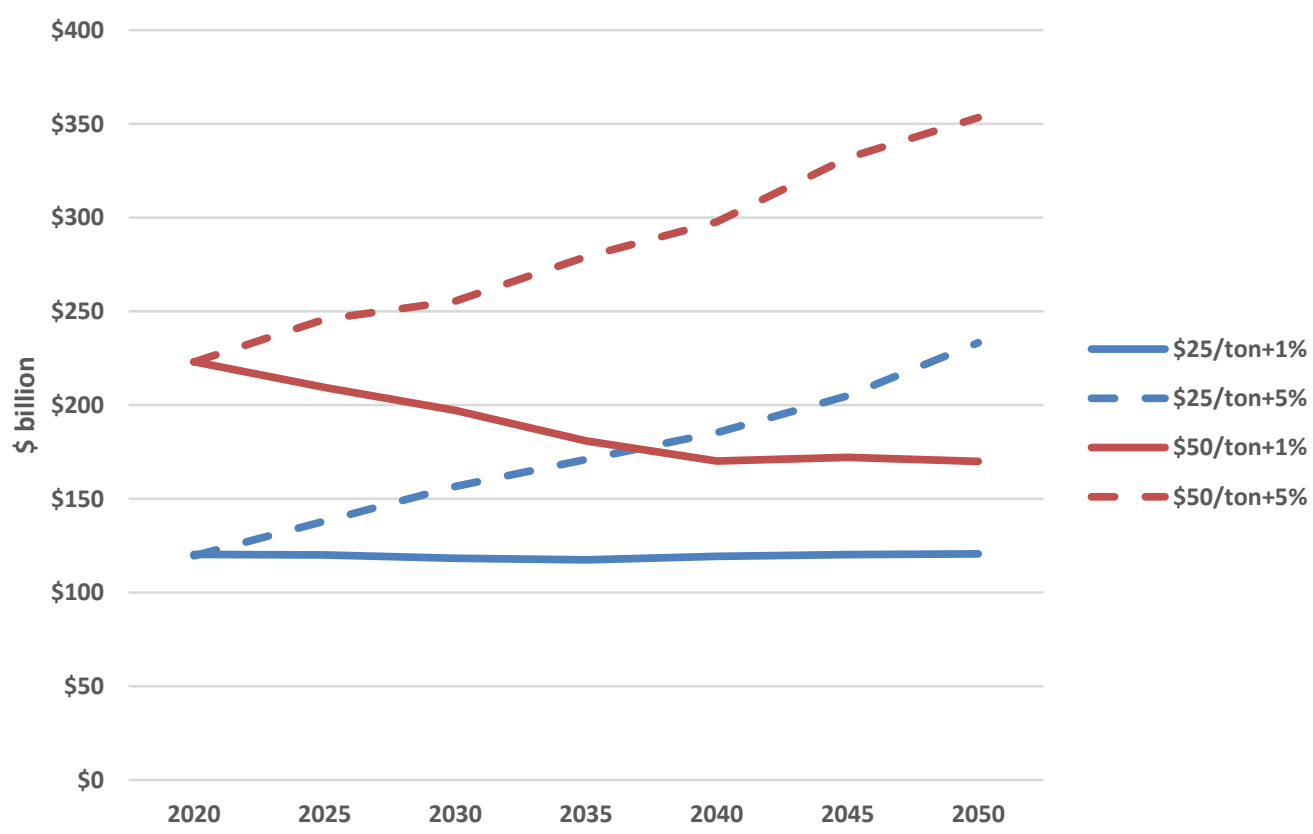

Figure 10. Carbon tax revenues for the alternative tax rates

In addition to providing emissions reductions, carbon taxes have the potential to generate substantial revenues, see Fig. 10 (note the inverse relationship between emissions reduction benefits and carbon tax revenues raised). In spite of the reductions shown in Figs. 7 and 8, the tax base of remaining emissions is large enough to generate (in gross terms prior to any revenues withheld by the government to offset other declines in tax receipts) around $\$ 120$ billion per year for the lowest $\$ 25 /$ ton tax rate, growing at $1 \%$ per year. The only option where tax revenues decline over time is the $\$ 50 /$ ton tax that grows at $1 \%$ per year. The two taxes growing at $5 \%$ per year continue to provide more revenue each year through 2050 , eventually reaching close to $\$ 250$ billion per year for the $\$ 25 /$ ton tax and more than $\$ 350$ billion for the $\$ 50 /$ ton tax.

\subsection{Macroeconomic impacts}

Over time, there are costs associated with carbon tax policies as the economy adjusts to a lower-emissions future. However, even the largest of these adjustments are trivial compared with the broader growth in the economy. Figure 11 presents the growth rates for baseline growth in the U.S. economy and the four carbon tax options considered, along with several revenue recycling options for the $\$ 25 /$ ton case, growing at $5 \%$.

The graph illustrates overall GDP trends and the legend gives the annual growth rates over the 2020-2050 time frame. In the baseline in the absence of a carbon tax, the economy grows at $2.27 \%$ per year (based on macroeconomic conditions from the AEO 2017). The highest carbon tax level $(\$ 50 /$ ton $+5 \%)$, after adjustments to energy production and consumption that result in significant declines in emissions, has a growth 


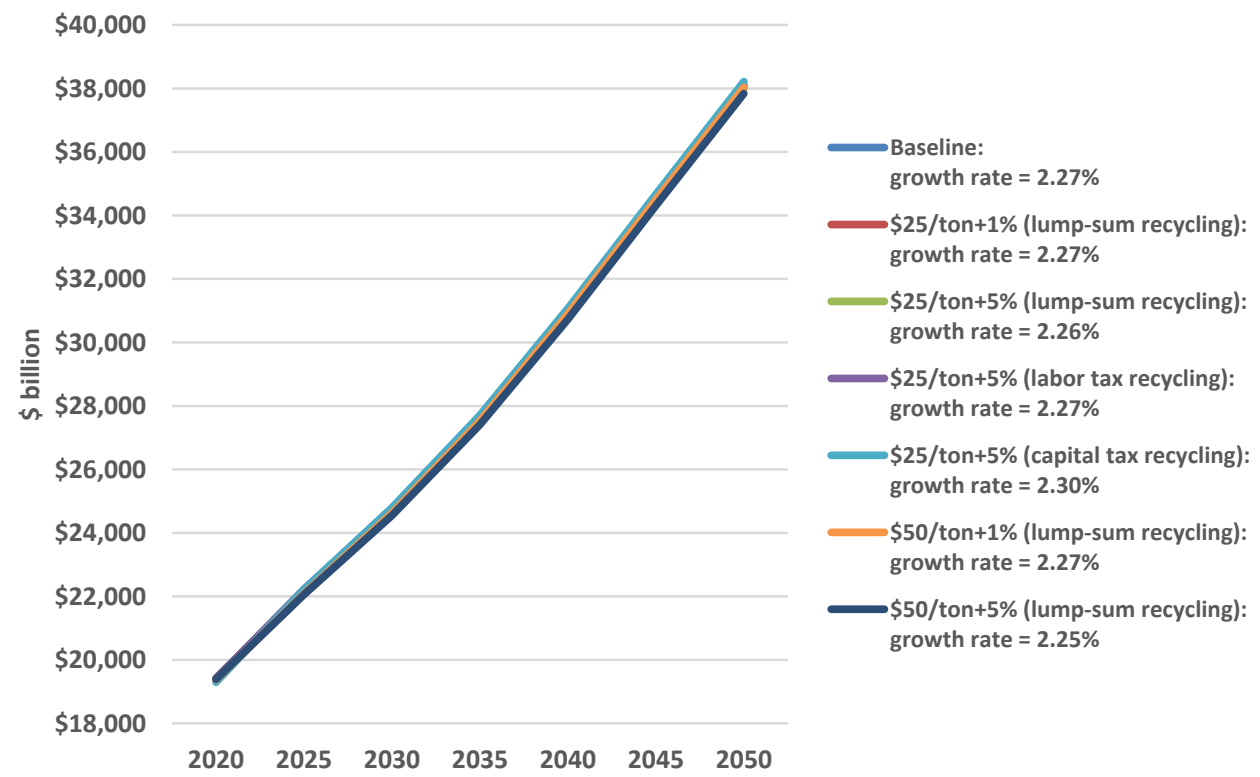

Figure 11. GDP growth in the United States: baseline versus carbon taxes

rate of $2.25 \%$ per year over the same time period, leaving the economy in essentially the same position after 30 years of the carbon tax policy. On the other side, the $\$ 25 /$ ton $+5 \%$ case with capital tax recycling has a growth rate slightly higher than the baseline at $2.30 \%$ per year, as the reductions in capital taxes result in additional economic growth (welfare for households on average still declines slightly in this case as shown in Fig. 11).

Table 2 presents the graphical information behind Fig. 11 as percent changes in GDP from baseline levels. The lump-sum and labor-tax recycling options for two levels of carbon taxes have similar temporal patterns; impacts in the near term are small and can even be positive as consumption shifts over time. Decreases in GDP grow slightly larger over the next 15-20 years before declining as the economy adjusts more fully to the carbon taxes. Labor-tax recycling has more beneficial effects on GDP

Table 2. U.S. GDP: percent changes from baseline for alternative carbon tax and recycling options.

\begin{tabular}{lcccrrrrr}
\hline Tax rate & Recycling & 2020 & 2025 & 2030 & 2035 & 2040 & 2045 & 2050 \\
\hline$\$ 25 /$ ton $+5 \%$ & Lump sum & $0.04 \%$ & $-0.27 \%$ & $-0.35 \%$ & $-0.42 \%$ & $-0.44 \%$ & $-0.38 \%$ & $-0.26 \%$ \\
& Labor tax & $0.02 \%$ & $-0.05 \%$ & $-0.10 \%$ & $-0.17 \%$ & $-0.21 \%$ & $-0.17 \%$ & $-0.07 \%$ \\
& Capital tax & $-0.61 \%$ & $-0.08 \%$ & $0.05 \%$ & $0.09 \%$ & $0.10 \%$ & $0.16 \%$ & $0.27 \%$ \\
$\$ 50 /$ ton $+5 \%$ & Lump sum & $-0.11 \%$ & $-0.76 \%$ & $-0.95 \%$ & $-1.00 \%$ & $-1.03 \%$ & $-0.89 \%$ & $-0.75 \%$ \\
& Labor tax & $-0.13 \%$ & $-0.35 \%$ & $-0.52 \%$ & $-0.60 \%$ & $-0.66 \%$ & $-0.55 \%$ & $-0.42 \%$ \\
& Capital tax & $-1.22 \%$ & $-0.30 \%$ & $-0.20 \%$ & $-0.19 \%$ & $-0.20 \%$ & $-0.06 \%$ & $0.09 \%$ \\
\hline
\end{tabular}


than lump-sum recycling as additional labor is encouraged to enter the market in response to increases in wage rates (see Fig. 13).

Capital-tax recycling, however, follows a much different pattern. Short-term losses in GDP are the largest as people shift forward in time in anticipation of coming benefits as the capital tax continues to decline into the future. These short-term losses are mostly experienced by existing capital stocks, as shown in Figs. 14 and 15. In the longer term, capital-tax recycling leads to the smallest GDP losses and has the potential to increase GDP.

The following graphs focus on the $\$ 25 /$ ton carbon tax, growing at 5\% per year, and examine how any macroeconomic impacts of taxes can be altered by the manner in which the carbon tax revenues are returned to households in the economy. Factor productivity, and hence factor prices, will be affected by adjustments to lower-emissions forms of production, consumption, and electricity generation. In 2030, Fig. 12 suggests that capital returns will decline by less than $0.5 \%$ on average. Impacts on overall labor prices, or wage rates, can vary significantly depending on how carbon tax revenues are used.

Unlike for labor, the average declines in capital returns are not divided equally between new capital and existing (or extant) capital that already been invested in industries or other capital stocks such as housing, commercial buildings, or vehicles. By 2030, many of these current, extant investments will have depreciated in value compared to what they are worth today, but some fraction of them will remain in existence. The fixed nature of these less-efficient stocks, based on today's technology, leave them in a more vulnerable position with regards to the taxes. The returns to these

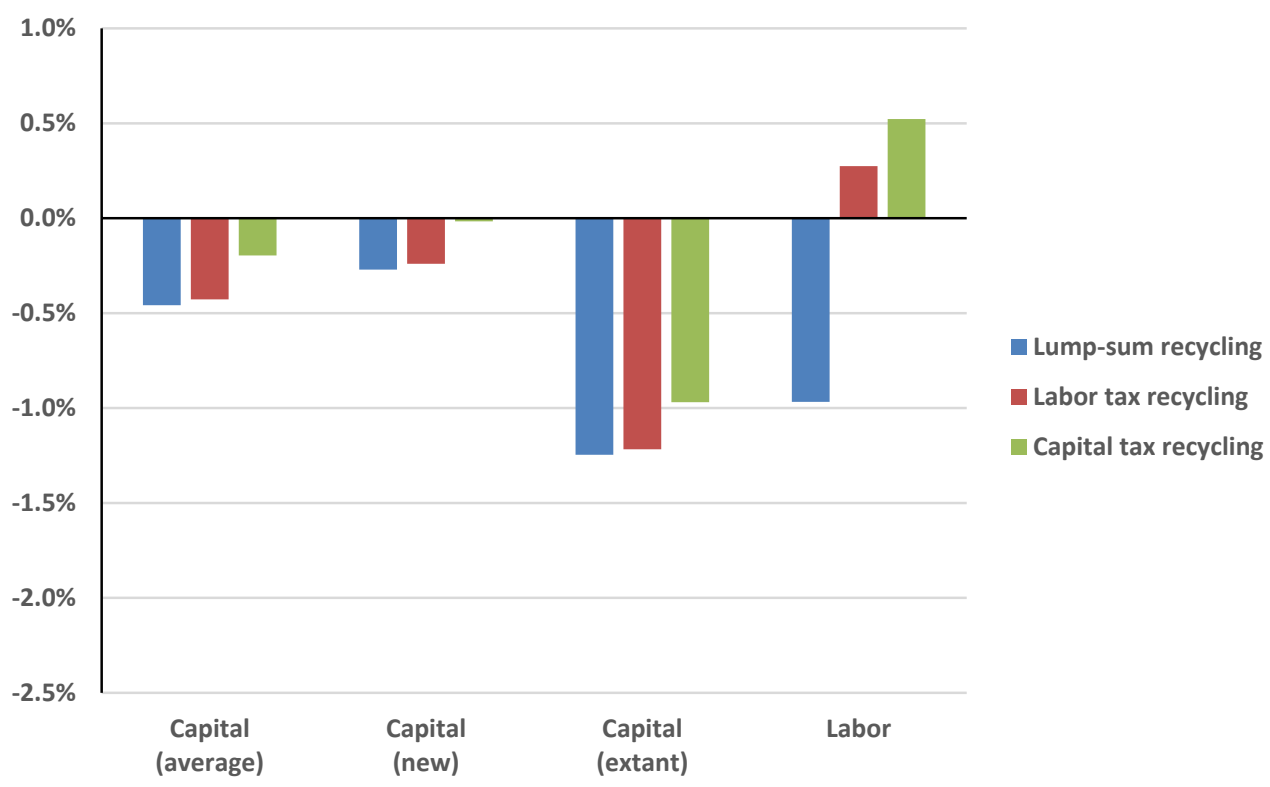

Figure 12. U.S. average factor price impacts in 2030 ( $\$ 25 /$ ton tax, growing at 5\%/year) 
current capital stocks are reduced by $1 \%$ or more in 2030. (Note that improvements in improving the efficiency of existing buildings, for example, would be considered new capital in the model).

New, more efficient investments installed after the start of the carbon tax policy have significantly smaller declines in productivity, and hence prices, than existing capital investments. This disparity, and the fact that extant capital is fixed in the region of the country where it is currently installed, can result in regional impacts that are different than the U.S. averages. Assumptions about who owns this capital, and overall differences in regional economies and energy consumption, will affect impacts on regional household welfare.

Labor is assumed to be interregionally immobile in the model, i.e., although people will be moving around the country in the future it is assumed they will not change these movements solely in response to the carbon tax policy. This immobility can cause changes in regional wage rates (shown in blue in Fig. 13 for the year 2030) that diverge from the U.S. averages (shown in red). Lump-sum recycling returns carbon revenues directly to households and has few implications for labor productivity (beyond the effects of the carbon taxes themselves). Declines in regional wages shown a pattern similar to the regional energy intensities shown in Fig. 3. The center of the country, which has the most energy production and consumption, has the largest declines in labor productivity as the regional economies adjust to the policy. Both coasts, which are less dependent on energy production and consume less energy today, have smaller adjustments and thus smaller changes in labor prices.

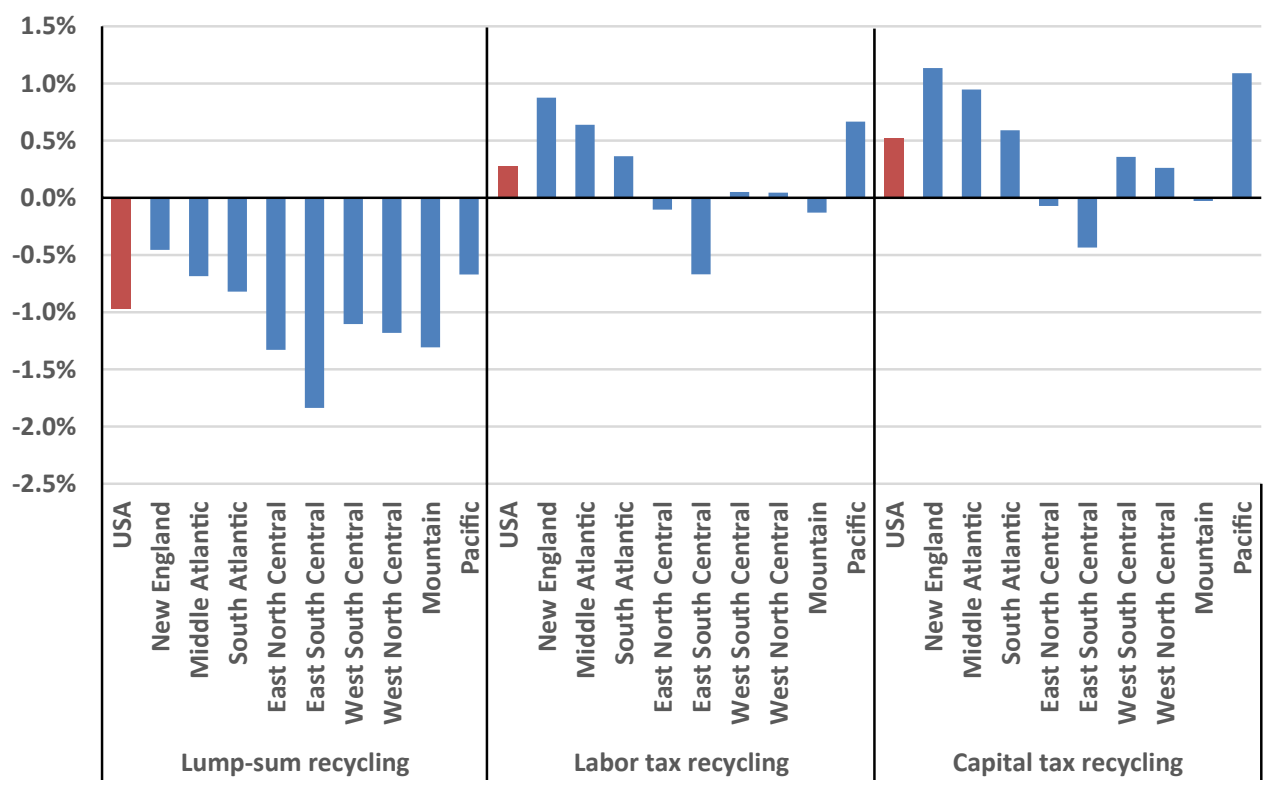

Figure 13. Labor price impacts in 2030 (\$25/ton tax, growing at 5\%/year) 
Recycling carbon revenues through labor taxes reduces the cost of hiring labor and improves its productivity per dollar spent. This gives a roughly proportional scaling up of the labor prices across regions. Wages rise on the two coasts of the country and any declines in the center of the country are mitigated. Effects of the capital tax recycling are similar, although for different reasons. Reducing capital taxes improves capital productivity. This productivity increase also makes labor more valuable as businesses invest more and then hire more people to work for them as a result.

Existing capital represents an interesting case in the modeling because its returns are dependent on economic conditions in the region where it is located, unlike other capital assets that earn the same return across regions (assuming that returns to new, flexible capital are smoothed across the country by well-functioning capital markets). Figure 14 shows how price changes of extant capital follow the same pattern as the overall structure of the regional economies and energy intensities. The two, less energy-intensive coasts have existing capital that is better adapted to a lower energy environment, while the middle of the country with its energy production and higher consumption have larger declines in capital earnings.

Given the fixed nature of the capital stocks, there is limited response to the different revenue recycling options. Lowering labor costs and improving its productivity has little effect on these capital returns. Similarly, since this capital is already in place and can not respond to the policy, lowering the marginal capital tax rate also does not affect its productivity. The slight scaling up of the capital earnings under the capital tax recycling case is the result of an overall improvement in economic conditions under this recycling option, rather than a function of the decline in capital taxes.

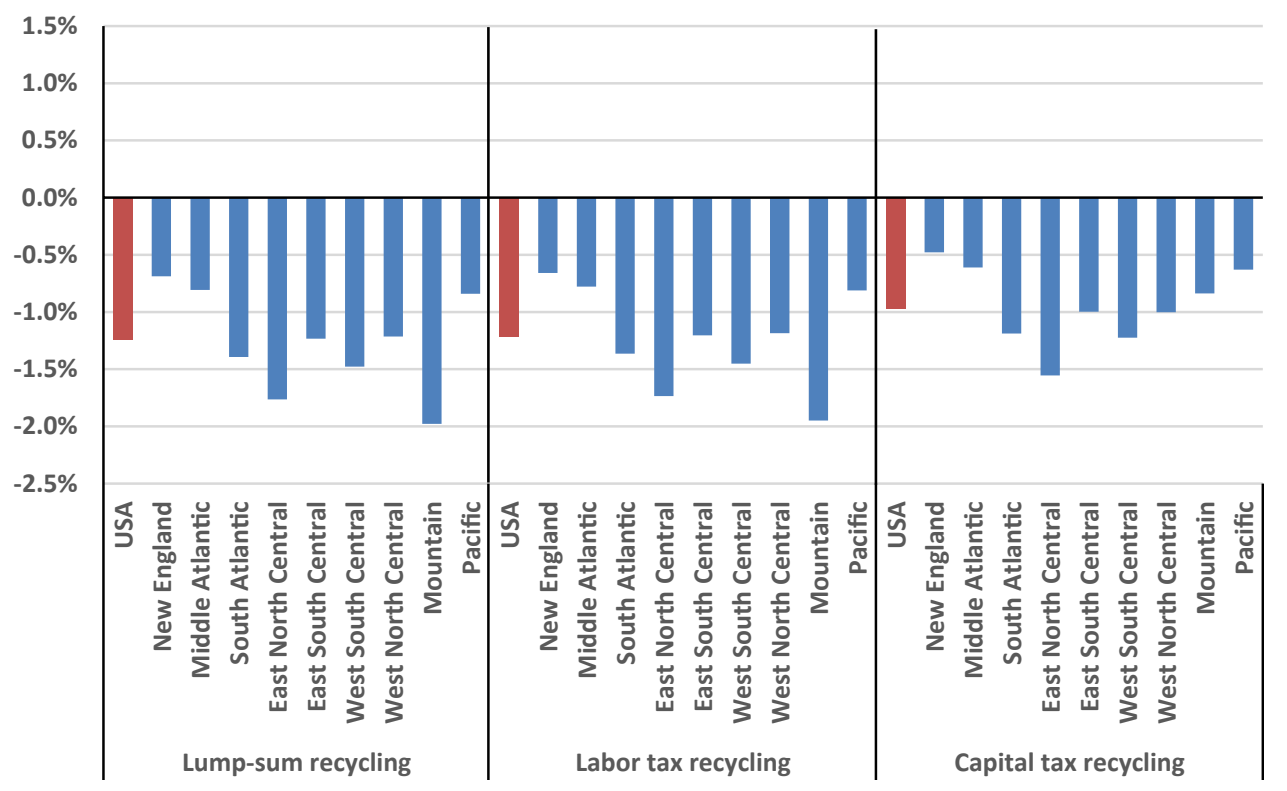

Figure 14. Extant capital price impacts in 2030 (\$25/ton tax, growing at 5\%/year) 


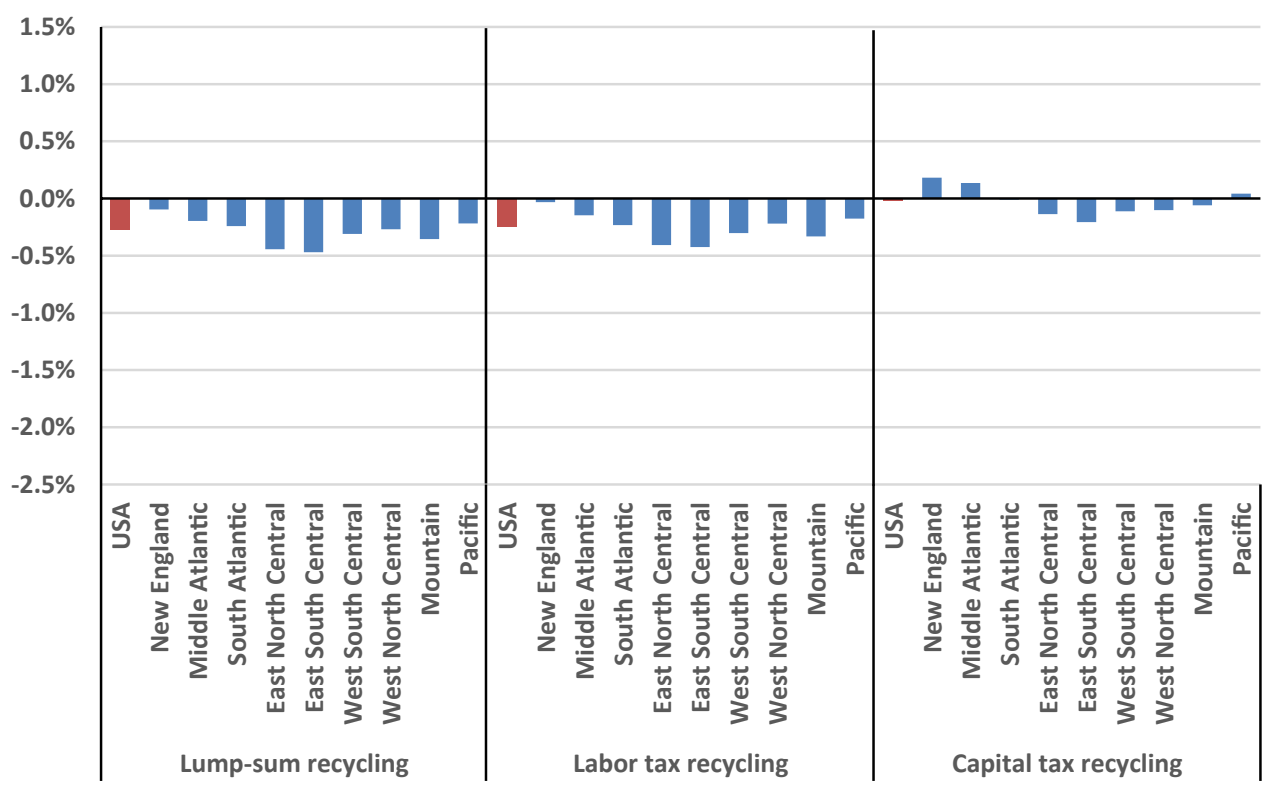

Figure 15. New capital price impacts in 2030 - differentiated markets $(\$ 25 /$ ton tax, growing at $5 \% /$ year)

Presumably, well-functioning capital markets will equilibrate returns to new capital across the country as investors demand the same capital return regardless of the location of new investments. These average impacts on returns to new investments are shown in Fig. 15 as the red bars for the United States as a whole. The regional bars in the graph pose the question of what might happen to returns to new capital if there were inefficiencies or frictions in capital markets that caused returns to vary across regions. In this extreme case, the effects follow the same regional pattern seen in other carbon tax impacts. All of these impacts are small compared to the losses seen by existing capital or the adjustments in wage rates across the different recycling options.

Figure 16 combines all of these changes in factor earnings, along with other factors, into an overall GDP impact for the different regions of the country in 2030. In almost all cases, the impacts are less than $0.5 \%$, even in the lump-sum recycling case that returns revenues directly to households and thus foregoes the ability to reduce inefficiencies in the economy caused existing tax distortions. To the extent that some regions have larger impacts, they tend to be located in the center of the country.

Recycling revenues through either labor or capital taxes generally scales up the graph, with some regions such as New England and the Pacific Coast experiencing increases in GDP as the result of the carbon tax and other regions seeing smaller declines than before. On average for the United States, there are few GDP impacts for either the labor or capital recycling options that reduce those marginal tax rates. 


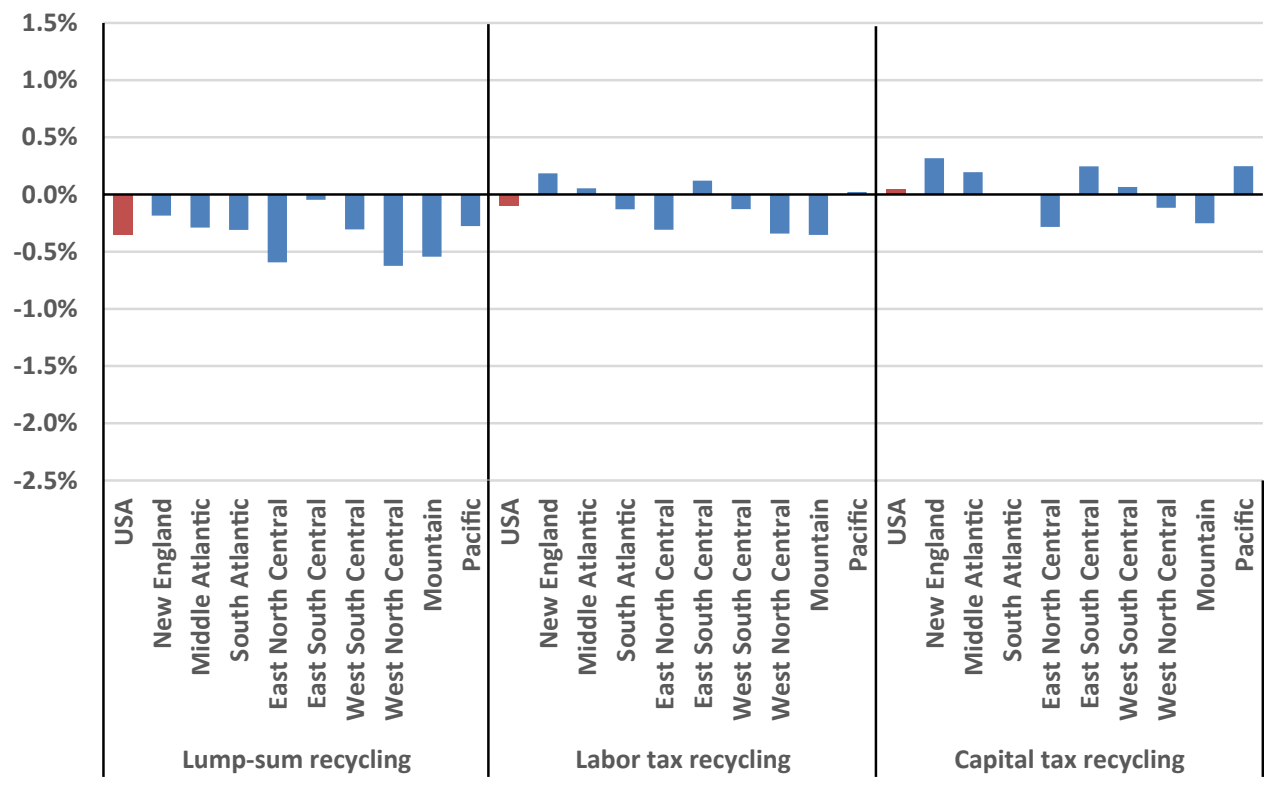

Figure 16. GDP impacts in 2030 (\$25/ton tax, growing at 5\%/year)

\subsection{Welfare impacts of recycling the carbon tax revenues}

Broader welfare measures of the costs of carbon tax policies follow similar regional patterns to those seen in the factor price and GDP measures. In these broader measures - calculated here as a comprehensive change in household equivalent variation (welfare) that considers changes in income, consumption of goods, and leisure time - there are less likely to be actual improvements from the policies than might be seen in individual factor impacts or even measures of economic activity such as GDP. Welfare impacts also consider all changes over time that result from the policies, rather than emphasize adjustments in a single year. As discussed in Rausch et al. (2011) and illustrated in the DIEM results in this paper, regional distributional issues can be more important than expected.

Figure 17 examines how different revenue recycling options can affect household welfare across the regions of the country for a $\$ 25 /$ ton carbon tax that grows at $5 \%$ per year. For the nation as a whole, the least efficient recycling (lump-sum) leads to a decline in welfare of around $0.3 \%$. Improving the efficiency of the economy by using revenues to lower labor taxes can reduce this U.S. impact to closer to $0.2 \%$. The most efficiencies are achieved by lowering capital tax rates, giving less than a $0.15 \%$ decline in welfare. These comprehensive measures show how policy revenues can be used to affect the impacts of the policy, however, for the country none of the options lead to overall increases in welfare, unlike what might be seen in a GDP measure for a particular year as shown in Fig. 16 for 2030.

It is easier for specific regions of the country, which are less affected by the policy, to see improvements in welfare across the recycling options, or at least see small 


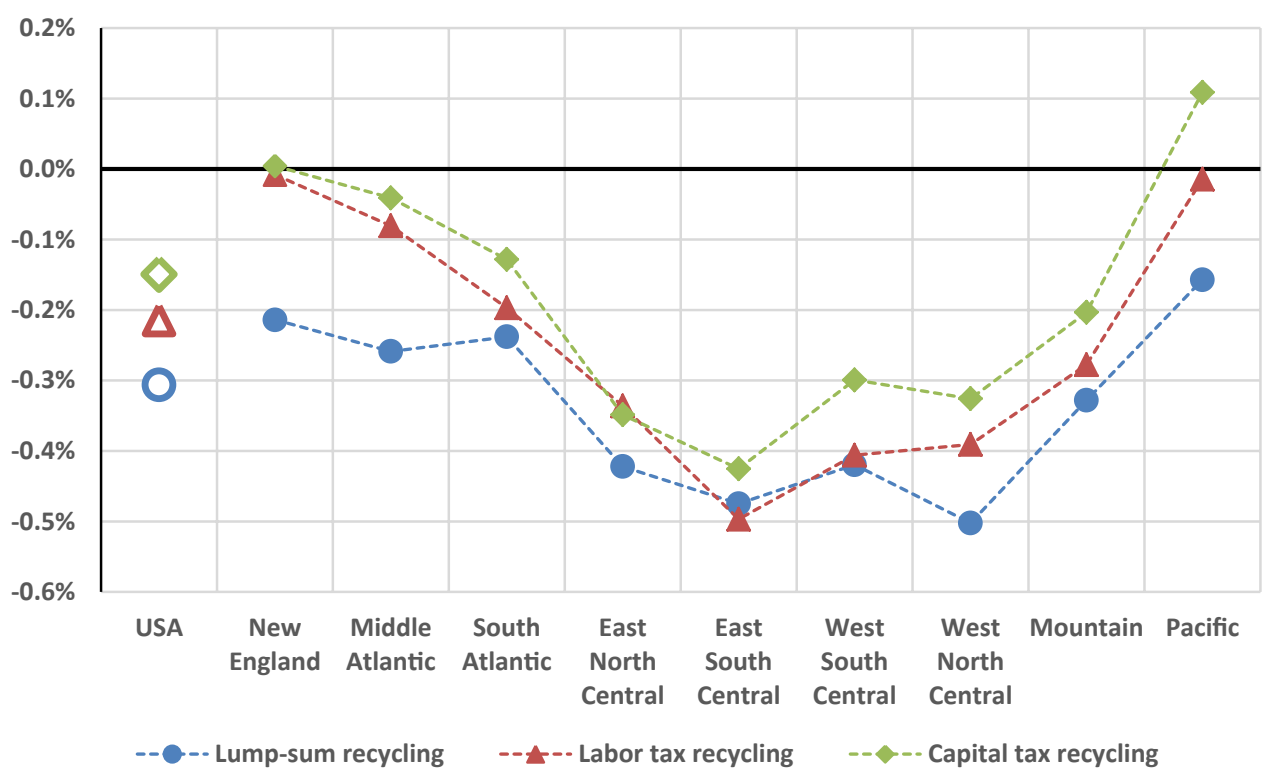

Figure 17. Regional welfare changes for revenue recycling options ( $\$ 25 /$ ton tax, growing at $5 \% /$ year)

declines in welfare. Again, the Northeast (New England and Middle Atlantic) have small declines in welfare, which may be reversed through recycling the revenues in efficient ways. The Pacific Coast is in a similar position since it is energy efficient and also capital intensive (which benefits from any capital tax recycling). The center of the nation tends to have declines on the order of $0.5 \%$, which can be improved but not offset by recycling revenues effectively.

The previous results assume that ownership of capital stocks - whether of existing capital or new investments and regardless of regional location - is spread across the households of the nation through perfect pooling of capital in a national stock market (this assumption is different from the assumption, which is maintained, that expected returns to capital are based on a national interest rate that represents the average value of capital). Figures 18-20 relax this assumption to explore how regional impacts of the policy may be affected if some capital is locally owned. The graphs distinguish between cases in which $100 \%$ of capital earnings are pooled across the country in capital markets (the standard assumption in this type of modeling), or if $50 \%$ of capital earnings are pooled and 50\% are owned locally, or in the extreme if $0 \%$ of earnings are pooled - implying that any capital is locally owned, thus accentuating any regional impacts of the policies.

Figure 18 shows how the assumption that $100 \%$ of capital earnings are pooled in national capital markets before being distributed to households (in blue) compares to the cases in which less capital is owned jointly across the country. Given than $63 \%$ of business earnings are controlled by pass-through entities, it seems reasonable to 
$0.2 \%$

$0.1 \%$

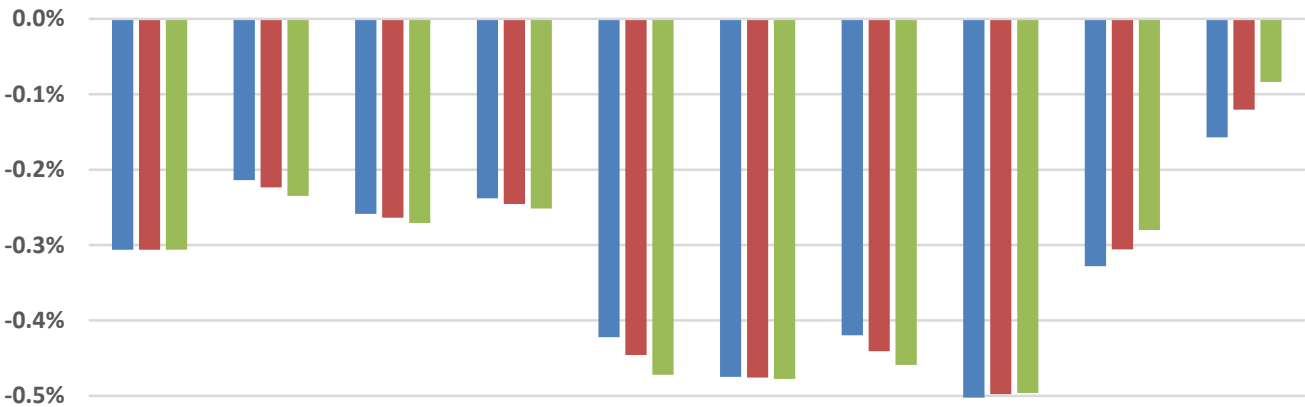

$-0.6 \%$

$\begin{array}{ccccccc}\text { USA } & \text { New } & \text { Middle } & \text { South } & \text { East North East South } & \text { West } & \text { West } \\ \text { England } & \text { Atlantic } & \text { Atlantic } & \text { Central Central } & \text { South } & \text { North } \\ \text { Central } & \text { Central } & \text { Pacific }\end{array}$

$-100 \% \quad-50 \% \quad-0 \%$

Figure 18. Welfare changes for lump-sum recycling — by share of capital in national capital markets ( $\$ 25 /$ ton tax, growing at $5 \% /$ year)

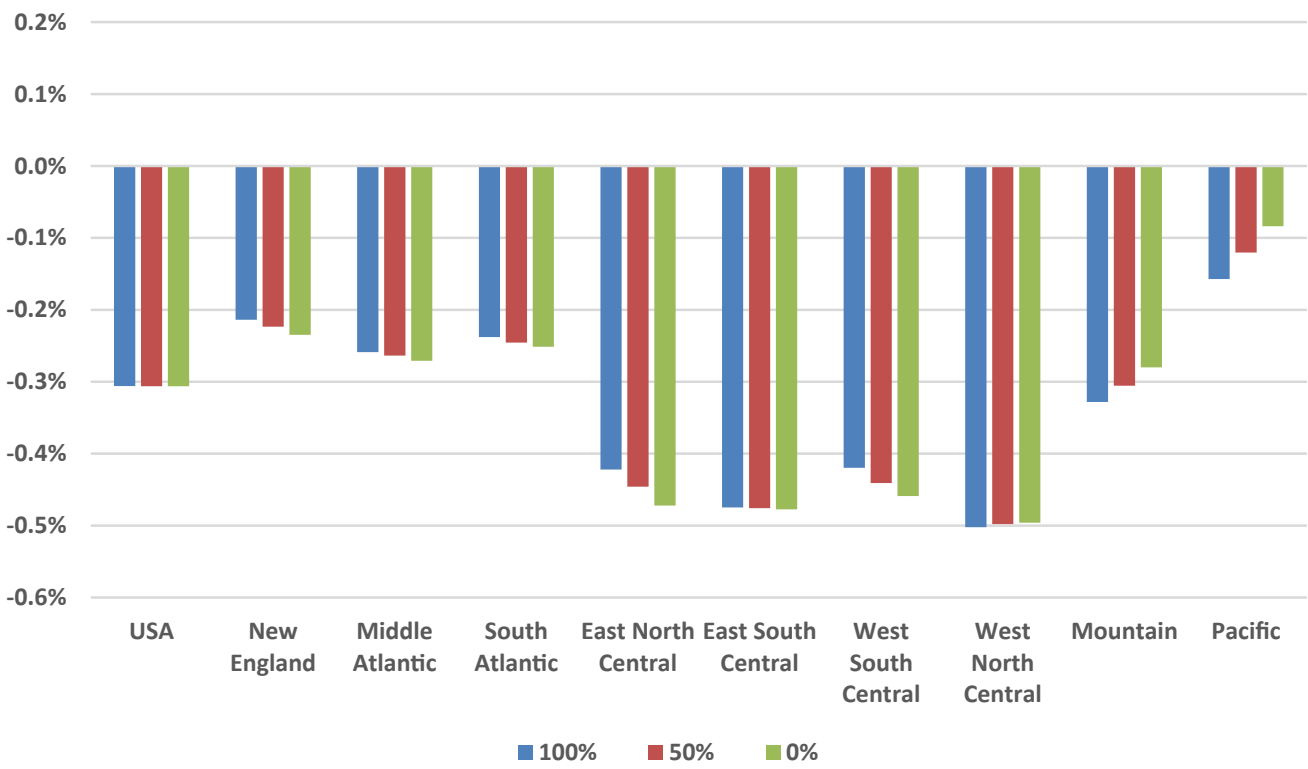

Figure 19. Welfare changes for labor tax recycling — by share of capital in national capital markets ( $\$ 25 /$ ton tax, growing at 5\%/year) 


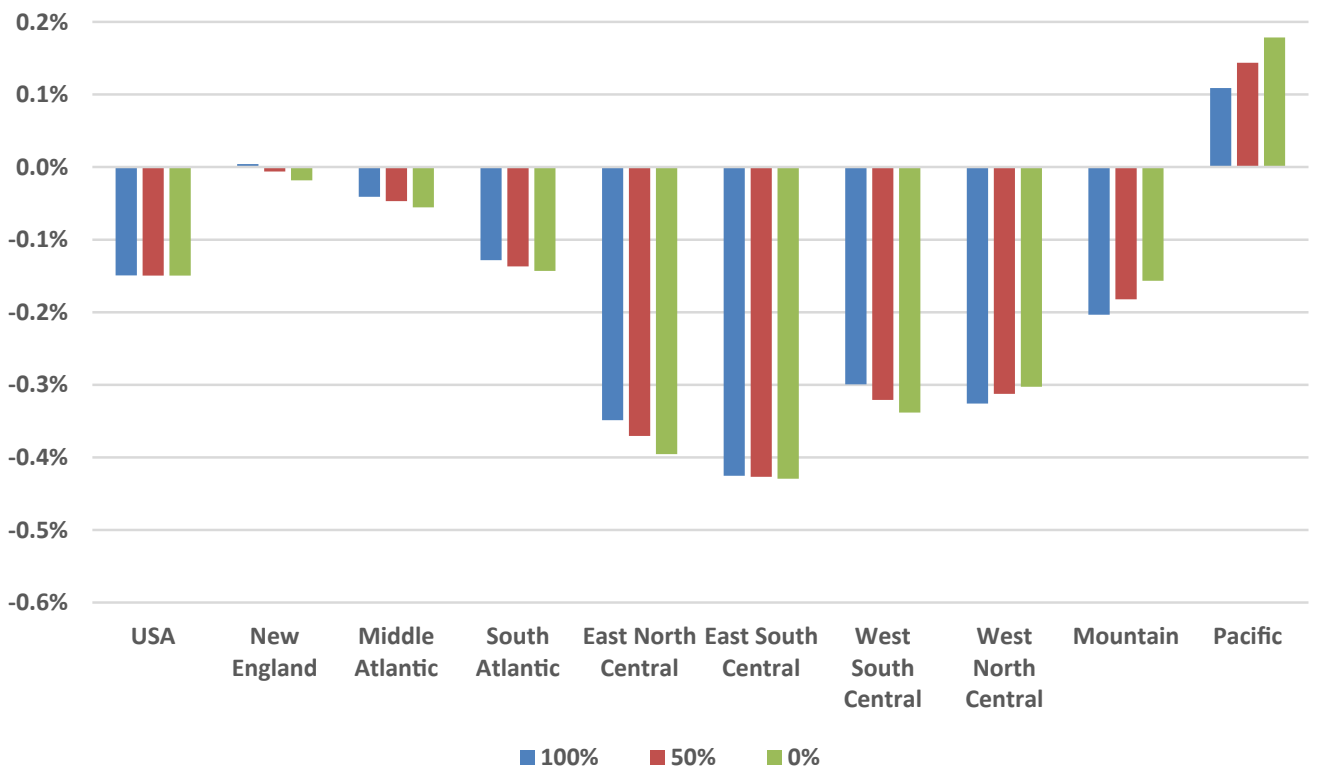

Figure 20. Welfare changes for capital tax recycling — by share of capital in national capital markets ( $\$ 25 /$ ton tax, growing at $5 \% /$ year)

assume these earnings by companies not traded on national markets may be concentrated in local regions. The general implication of adjusting the ownership assumption is to accentuate regional differences in policy impacts. At the national level, how capital earnings are distributed does not affect average household welfare. However, assuming that households in the West own a capital portfolio that is concentrated in the West, which experiences smaller policy impacts, will lead to smaller welfare impacts for those households. Interestingly, this pattern does not hold in New England, apparently because their earnings are more concentrated in labor than other regions. The middle of the country is usually worse off if they own capital assets that are specific to their own regions that are more adversely affected by the carbon policy. Similar patterns hold for both the labor-tax and capital-tax recycling options as well.

\section{Conclusions}

This analysis has looked at the potential economic implications of carbon tax proposals. Addressing the concerns of businesses and households about energy costs will be an important factor in determining the viability of using these tax instruments to lower emissions in the United States. Such policies have implications for household consumption that can vary across household income classes. Regional differences also play a role in determining the impacts of carbon tax policies. One method for offsetting these impacts is to use the revenues generated to lower costs to households or to lower labor and capital tax rates that affect both household and business decisions. 
How successful these options are will tend to vary across regions of the country, depending on the structure of local economies.

Broadly, the analysis finds that taxes are a feasible way to reduce emissions. The size of these reductions can be significant, although it is unclear how successful any given tax rate may be in meeting long-term goals such as an $80 \%$ reduction below 2005 emissions levels by 2050. The macroeconomic adjustments associated with carbon taxes starting in the $\$ 25-\$ 50 /$ ton range are not very large and have little effect on overall economic growth. Using the substantial revenues generated by carbon taxes to supplement household income or lower existing labor and capital taxes can help offset any costs imposed on households by the carbon tax.

It will be important to consider how regional differences in manufacturing and household consumption may interact with carbon taxes. Today, there are important variations across the parts of the country in production technologies, the availability of natural resources availability and energy consumption patterns that will make it easier/ harder for regions to reduce cost-effectively emissions. Some parts of the country such as the Northeast and the West Coast have comparatively small responses to a carbon tax because they have manufacturing/service industries and electricity generation that are less carbon-intensive today; other areas in the South and the middle of the country see effects that are above the national averages, given that they are comparatively more carbon intensive and are also more reliant on fossil-fuel production. These regional disparities tend to occur across labor and capital returns, and in overall GDP and consumption impacts.

While revenue recycling options can affect national economic impacts of carbon taxes, unless these revenues are targeted in some fashion to specific regions, they will do little to change disparities in regional policy costs. How capital ownership is distributed across the nation, which remains an open question, can also exaggerate regional differences in these impacts. Model results show that this distribution will influence how regions respond to a carbon tax. Considering all of these factors will be necessary when evaluating how to distribute revenues from any carbon tax in order to alleviate disproportionate burdens on both households and states around the United States.

\section{Acknowledgments}

The work reported here has benefitted from input and feedback from participants in the Stanford Energy Modeling Forum and colleagues at the Nicholas Institute, including Brian Murray and Billy Pizer. The analysis conducted herein was partially supported by a grant from The Energy Foundation; model development was partially supported by a gift from Bank of America Merrill Lynch. All errors and omissions are those of the author. 


\section{Appendix A. Model Structure}

Households have capital-energy structure similar to the logic used for manufacturing industries (see Fig. A.1). Households decide between spending income on housing services (houses plus the energy that makes them comfortable) and all other consumption goods. In addition to specifying the capital-energy tradeoff, DIEM-CGE follows the approach in Bovenberg et al. (2005) and distinguishes between capital used in manufacturing and capital used in the housing stock. This allows the model to be explicit about opportunities for improving the energy efficiency of housing through the investment of capital to reduce energy consumption.

A similar capital-energy structure is also applied to the capital stock representing personal vehicles (Fig. A.2). Households can choose to purchase transport such as

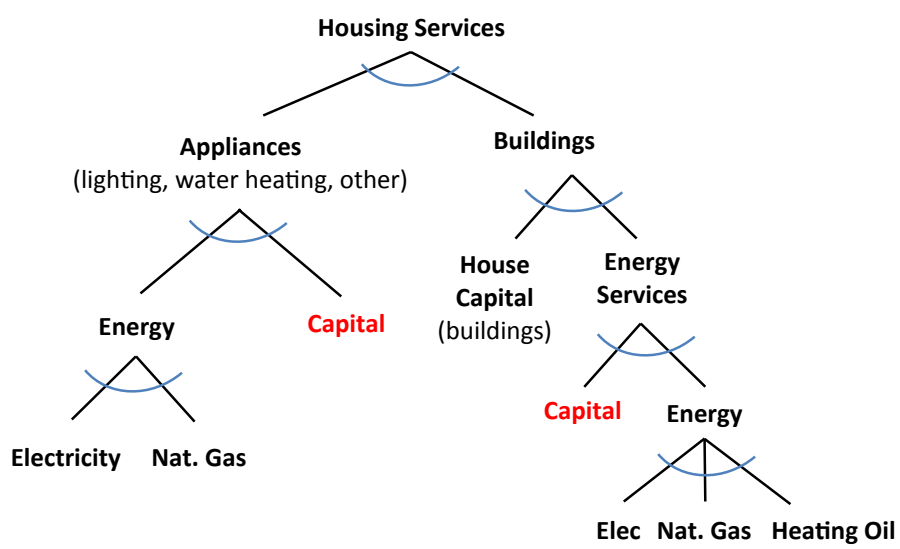

Figure A.1. Housing services.

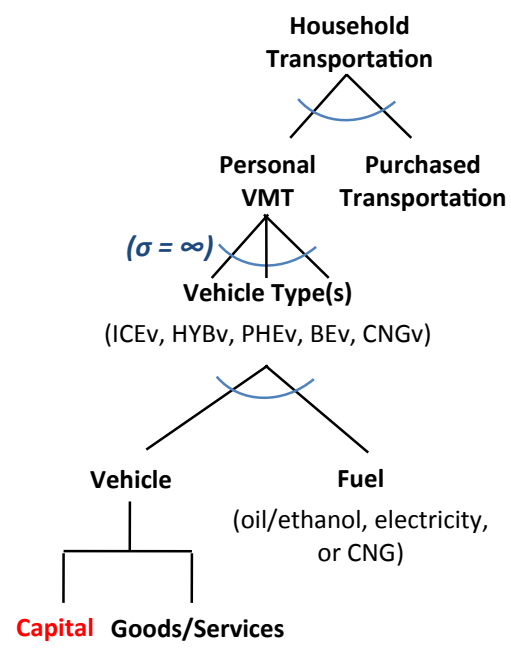

Figure A.2. Transportation services 


\section{T. Ross}

airline flights and to invest in transport provided by personal light-duty vehicles (LDV) that provide "vehicle miles traveled" (VMT). Several types of LDV are available in the model: conventional internal-combustion engine vehicles (ICEv), hybrid gas-electric vehicles $(\mathrm{HYBv})$, plug-in hybrid electric vehicles (PHEv), battery electric vehicles $(\mathrm{BEv})$, and compressed natural gas vehicles (CNGv). Capital can be invested in new vehicles to improve their miles per gallon (MPG) efficiency - existing vehicles cannot improve MPG and depreciate away.

Electricity has a unique production structure to handle generation of a similar commodity by a variety of different technologies (see Fig. A.3). This production

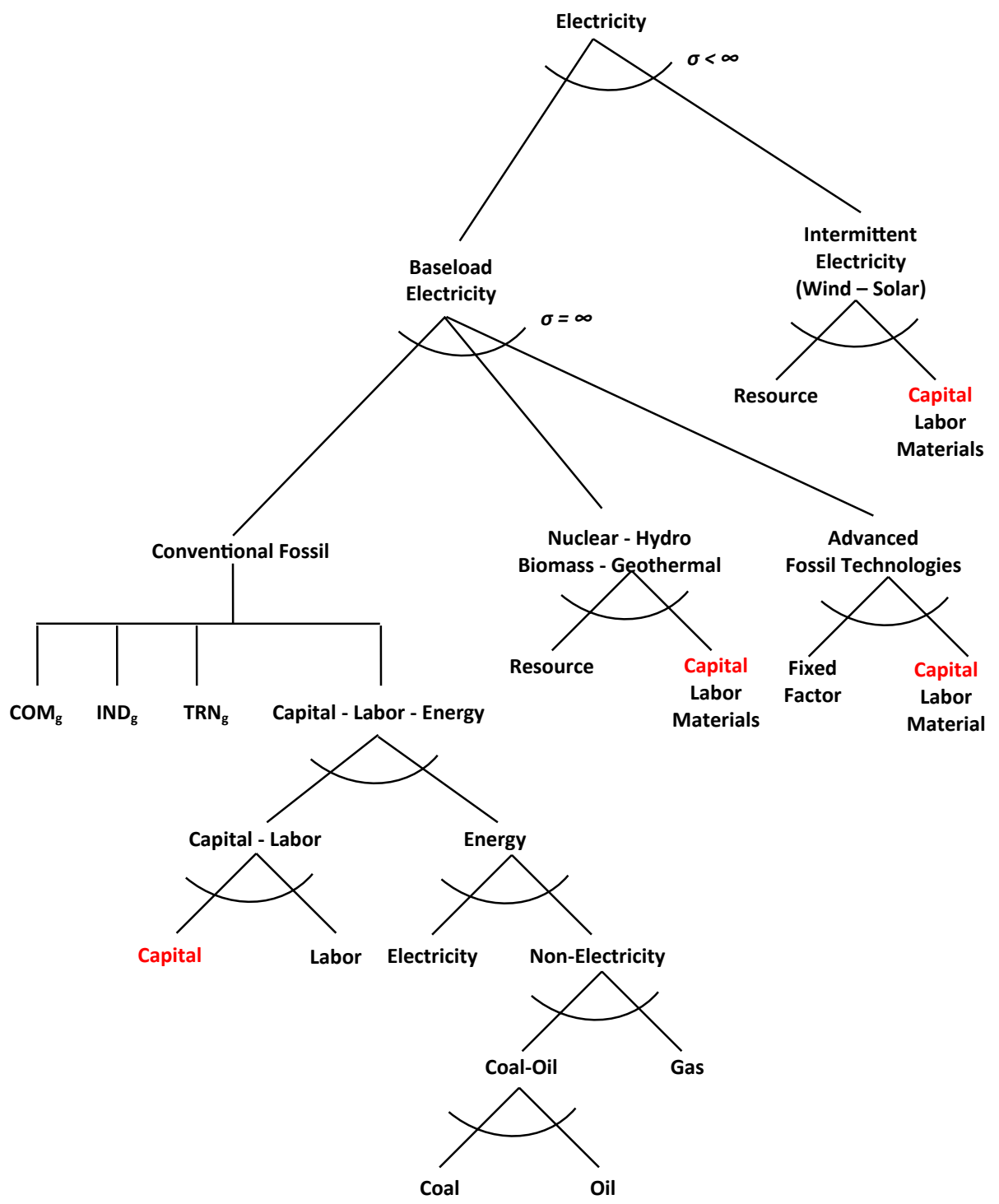

Figure A.3. Electricity generation 
provides several options to improve efficiency in the industry: (1) by improving conventional technologies, (2) by investing in new technologies, and (3) by expanding intermittent wind and solar generation - intermittent sources produce a slightly differentiated electricity commodity compared to baseload units. Following Böhringer (1998), McFarland et al. (2004), and Böhringer and Rutherford (2008), the second two options allow the model to combine the standard "top-down" nested CES equations with "bottom-up" engineering data on the costs and characteristics of specific technologies.

Information on the types of "Advanced Fossil Technologies" - advanced gas combined cycle (NGCC), NGCC with carbon capture and storage (CCS), and integrated coal gasification combined cycle with CCS - are added to the model based on Paltsev et al. (2005). Current cost estimates for these technologies are taken from the AEO 2017 (EIA, 2017a). Wind and solar options are included using costs from both the AEO 2017 and NREL's Annual Technology Baseline (NREL, 2016).

Specific regional costs, along with the expansion paths for each type of technology in the DIEM-CGE model, are calibrated to data and policy simulations from the DIEM-Electricity dispatch model of generation (see the forthcoming Ross (2018) for a discussion of these results in detail). This analysis uses a joint approach to combine DIEM-CGE simulations with more detailed electricity results from the DIEM-Electricity model, rather than a "hard linkage" that attempts to iterate both models to a consistent solution, because of difficulties in achieving a close enough correspondence between the two models' cost structure to enable examination of policy's welfare results.

The different approaches to capital costs in the two types of models, CGE versus electricity dispatch, make it problematic to be consistent enough in "hard, iterated linkage" to be confident in the welfare results. However, by calibrating the electricity generation decisions in DIEM-CGE used in this analysis to choices for the same policies in DIEM-Electricity, it is possible to maintain the logical structure of the CGE model without sacrificing the more detailed findings from the electricity dispatch model. This calibration without direct replacement of results yields better welfare results for this distributional analysis. Essentially, reactions to a carbon tax by specific types of generation (coal retirements, new NGCC or solar construction, etc.) are provided by the dispatch model. Growth rates in these types of generation - and the same cost structure - are used in the CGE model, which is allowed to internally estimate, for example, losses by existing coal-unit capital that are a part of the CGE model, but not considered by the dispatch model.

\section{References}

Aldy, J and W Pizer (2011). The competitiveness impacts of climate change mitigation policies. NBER working paper No. 17705. Available at http://www.nber.org/papers/w17705.

Arrow, KJ and G Debreu (1954). Existence of an equilibrium for a competitive economy. Econometrica, 22, 265-290. 
Arrow, KJ and FH Hahn (1971). General Competitive Analysis. Holden-Day: San Francisco.

Ballard, C (2000). How many hours are in a simulated day? The effect of time endowment on the results of tax-policy simulation models. Discussion paper, Michigan State University, MI.

Böhringer, C (1998). The synthesis of bottom-up and top-down in energy policy modeling. Energy Economics, 20, 233-248.

Böhringer, C and TF Rutherford (2008). Combining bottom-up and top-down. Energy Economics, 30, 574-596.

Bovenberg, LA and LH Goulder (1996). Optimal environmental taxation in the presence of other taxes: General-equilibrium analysis. American Economic Review, 86(4), 985, 1000.

Bovenberg, A, L Goulder and J Gurney (2005). Efficiency costs of meeting industry-distributional constraints under environmental permits and taxes, RAND Journal of Economics, 36(4), 951-71.

Burtraw, D, R Sweeney and M Walls (2009). Distributional impacts of carbon pricing policies in the electricity sector. RFF Discussion Paper. Available at http://www.rff.org/files/sharepoint/WorkImages/Download/RFF-DP-09-43.pdf.

Carbone, J, R Morgenstern, R Williams and D Burtraw (2013). Deficit reduction and carbon taxes: Budgetary, economic, and distributional impacts. RFF Report August 2013, Available http://www.rff.org/research/publications/deficit-reduction-and-carbon-taxes-budgetary-economic-and-distributional.

Congressional Budget Office (CBO) (2014). Taxing capital income: Effective marginal tax rates under 2014 law and selected policy options. Available at https://www.cbo.gov/publication/ 49817.

Congressional Budget Office (CBO) (2016). An update to the budget and economic outlook: 2016 to 2026. Available at http://www.cbo.gov/publication/51908.

Dinan, T (2012). Offsetting a carbon tax's costs on low-income households. CBO working paper 2012-16. Available at https://www.cbo.gov/sites/default/files/112th-congress-20112012/workingpaper/11-13LowIncomeOptions_0.pdf.

Electric Power Research Institute (2017). US-REGEN Model Documentation. EPRI Project Manager David Young, Available at http://eea.epri.com/models.html.

Fawcett, AA, LC Clarke and JP Weyant (2015). Carbon taxes to achieve emissions targets: Insights from EMF 24. In Implementing a US Carbon Tax: Challenges and Debates. I Parry, A Morris and RC Williams III (eds.), pp. 62-82. London: International Monetary Fund and Routledge.

Feenberg, D and E Coutts (1993). An introduction to the TAXSIM model. Journal of Policy Analysis and Management, 12(1), 189-194, http://www.nber.org/ taxsim/.

Fuchs, VR, AB Krueger and JM Poterba (1998). Economists' views about parameters, values, and policies: Survey results in labor and public economics. Journal of Economic Literature, 36, 1387-1425.

GAMS Development Corporation (2012). GAMS: A User's Guide. Available at http://www. gams.com/. Accessed on Feb 15, 2016.

Goulder, LH, IWH Parry and D Burtraw (1997). Revenue-raising versus other approaches to environmental protection: The critical significance of preexisting tax distortions. RAND Journal of Economics, 28, 708-731.

Hafstead, M and R Kopp (2016). Analysis of the American Opportunity Carbon Fee Act of 2015 (S. 1548)." RFF Policy Brief 15-01-REV. Available at http://www.rff.org/research/ publications/analysis-american-opportunity-carbon-fee-act-2015-s-1548.

International Energy Agency (IEA) (2016). World Energy Outlook - 2016. Available at http://www.worldenergyoutlook.org/. 
Internal Revenue Service (IRS) (2017). SOI tax stats — business tax statistics. Available at https://www.irs.gov/statistics/soi-tax-stats-business-tax-statistics.

Lanz, B and S Rausch (2011). General equilibrium, electricity generation technologies and the cost of carbon abatement: A structural sensitivity analysis. Energy Economics, 33, 1035-1047.

Lau, M, A Pahlke and T Rutherford (2002). Approximating infinite-horizon models in a complementarity format: A primer in dynamic general equilibrium analysis. Journal of Economic Dynamics and Control, 26(4), 577-609.

Mathur, A and A Morris (2012). Distributional effects of a carbon tax in broader U.S. fiscal reform. Brookings Climate and Energy Economics Discussion Paper. Available at https:// www.brookings.edu/wp-content/uploads/2016/06/14-carbon-tax-fiscal-reform-morris.pdf.

McFarland, J, J Reilly and HJ Herzog (2004). Representing energy technologies in top-down economic models using bottom-up information. Energy Economics, 26, 685-707.

McKibbin, W, A Morris, P Wilcoxen and Y Cai (2015). Carbon taxes and U.S. fiscal reform, National Tax Journal, 68(1), 139-156.

Metcalf, GE, A Mathur and KA Hassett (2010). Distributional impacts in a comprehensive climate policy package. NBER Working Paper w16101.

Minnesota IMPLAN Group (2012). State-level U.S. data for 2010. Stillwater. Minnesota IMPLAN Group, MN.

Murray, B, W Pizer and M Ross (2015). Regulating existing power plants under the U.S. clean air act: Present and future consequences of key design choices. Energy Policy, 83, 87-98. Available at http://www.sciencedirect.com/science/article/pii/S0301421515001421.

Narayanan, G Badri and Terrie L Walmsley (Eds.) (2008). Global Trade, Assistance, and Production: The GTAP 7 Data Base, Center for Global Trade Analysis, Purdue University. Available online at: http://www.gtap.agecon.purdue.edu/databases/v7/v7_doco.asp.

NREL (National Renewable Energy Laboratory) (2016). Annual Technology Baseline. Available at http://www.nrel.gov/analysis/data_tech_baseline.html.

Paltsev, S, JM Reilly, HD Jacoby, RS Eckaus, J McFarland, M Sarofim, M Asadoorian and M Babiker (2005). The MIT Emissions Prediction and Policy Analysis (EPPA) Model: Version 4. MIT Joint Program on the Science and Policy of Climate Change, Report\#125.

Parry, Ian WH and AM Bento (2000). Tax deductions, environmental policy, and the 'double dividend' hypothesis. Journal of Environmental Economics and Management, 39, 67-96.

Phelps, ES (1963). Substitution, fixed proportions, growth and distribution. International Economic Review, 4, 265-288.

Rausch, S, G Metcalf and J Reilly (2011). Distributional impacts of carbon pricing: A general equilibrium approach with micro-data for households. Energy Economics, 33(S1), S20-S33. Available at https://ideas.repec.org/a/eee/eneeco/v33y2011is1ps20-s33.html.

Rausch, S and M Mowers (2012). Distributional and efficiency impacts of clean and renewable energy standards for electricity. MIT Joint Program on the Science and Policy of Climate Change, Report\#225.

Rausch, S and J Reilly (2015). Carbon taxes, deficits, and energy policy interactions, National Tax Journal, 68(1), 157-178.

Ross, M (2014a). Structure of the dynamic integrated economy/energy/emissions model: Computable general equilibrium component, DIEM-CGE. NI WP 14-12. Durham, NC: Duke University. Available at http://nicholasinstitute.duke.edu/environment/publications/structuredynamic-integrated-economyenergyemissions-model-computable-general-equilbrium.

Ross, M (2014b). Structure of the dynamic integrated economy/energy/emissions model: Electricity component, DIEM-Electricity. NI WP 14-11. Durham, NC: Duke University. 
Available at http://nicholasinstitute.duke.edu/environment/publications/structure-dynamicintegrated-economyenergyemissions-model-electricity-component-diem.

Ross, M, D Hoppock and B Murray (2016). Ongoing evolution of the electricity industry: Effects of market conditions and the clean power plan on states. NI WP 16-07. Durham, NC: Duke University. Available at http://nicholasinstitute.duke.edu/publications.

Ross, M (2018). Technology adoption in the electricity industry. Forthcoming in Energy Economics.

Russek, FS (1996). Labor Supply and Taxes. Congressional Budget Office, Washington D.C. Available at ftp://ftp.cbo.gov/33xx/doc3372/labormkts.pdf.

Rutherford, TF (1999). Applied general equilibrium modeling with MPSGE as a GAMS subsystem: An overview of the modeling framework and syntax. Computational Economics, 14(1), 1-46.

Rutherford, TF (2004). Tools for building national economic models using state-level IMPLAN social accounts. University of Colorado, Boulder, CO. Available at http://debreu.colorado. edu/implan98.htm.

Rutherford, TF and D Tarr (2008). Poverty effects of Russia's WTO accession: Modeling "real" households with endogenous productivity effects. Journal of International Economics, 75(1), 131-150.

Tax Foundation (2017a). State corporate income tax rates. Available at https://taxfoundation. org/state-tax/corporate-income-taxes/.

Tax Foundation (2017b). Corporate income tax rates around the world, 2017. Available at https://taxfoundation.org/corporate-income-tax-rates-around-the-world-2017/.

U.S. Bureau of Economic Analysis (BEA) (2017). Regional Data - State GDP. Available at https://www.bea.gov/regional/index.htm.

U.S. Bureau of Labor Statistics (BLS) (2016). Consumer expenditure survey. Available at http://www.bls.gov/cex/.

U.S. Census Bureau (Census) (2017). Population Projections. Available at https://www.census. gov/programs-surveys/popproj/data/datasets.html.

U.S. EIA (Energy Information Administration) (2017a). Available at Annual Energy Outlook 2017. http://www.eia.gov/forecasts/aeo/.

U.S. EIA (Energy Information Administration) (2017b). Assumptions to the annual energy outlook 2017. Available at http://www.eia.gov/forecasts/aeo/assumptions/.

U.S. EIA (Energy Information Administration) (2017c). State energy data system. Available at https://www.eia.gov/state/seds//.

U.S. EIA (Energy Information Administration) (2017d). Electricity power annual 2015 — State Historical Tables. Available at https://www.eia.gov/electricity/annual/.

U.S Environmental Protection Agency (EPA) (2012). Global Anthropogenic Non- $\mathrm{CO}_{2}$ Greenhouse Gas Emissions: 1990-2030. EPA \#430-S-12-002. Available at https://www.epa. gov/global-mitigation-non-co2-greenhouse-gases/global-anthropogenic-non-co2-greenhouse-gas-emissions.

U.S Environmental Protection Agency (EPA) (2017). Inventory of U.S. Greenhouse Gas Emissions and Sinks: 1990-2015. EPA \#430-P-17-001. Available at https://www.epa.gov/ ghgemissions/inventory-us-greenhouse-gas-emissions-and-sinks-1990-2015.

U.S. Government Accountability Office (GAO) (2013). Corporate income tax: Effective tax rates can differ significantly from the statutory rate. GAO-13-520. Available at http://www. gao.gov/assets/660/654957.pdf.

Williams, RC, III (1999). Revisiting the cost of protectionism: The role of tax distortions in the labor market."Journal of International Economics, 47, 429-447. 
Williams, R, H Gordon, D Burtraw, J Carbone and R Morgenstern (2015). The initial incidence of a carbon tax across income groups, National Tax Journal, 68(1), 195-214.

Williams, R and C Wichman (2015). Macroeconomic effects of carbon taxes. In Implementing a US Carbon Tax: Challenges and Debates. Ian Parry, Adele Morris and Roberton C Williams III (eds.). Routledge Explorations in Environmental Economics (Book 44). Available at https://search.library.duke.edu/search?id=DUKE006501419. 